\title{
The Differential Expression of Mevalonate Pathway Genes in the Gut of the Bark Beetle Dendroctonus rhizophagus (Curculionidae: Scolytinae) Is Unrelated to the de Novo Synthesis of Terpenoid Pheromones
}

\author{
Laura Elisa Sarabia ${ }^{1}$, María Fernanda López ${ }^{1}$, Gabriel Obregón-Molina ${ }^{1}$, \\ Claudia Cano-Ramírez ${ }^{1}$, Guillermo Sánchez-Martínez ${ }^{2}$ (D) and Gerardo Zúñiga ${ }^{1, *}$ \\ 1 Laboratorio de Variación Biológica y Evolución, Departamento de Zoología, Escuela, Nacional de Ciencias \\ Biológicas, Instituto Politécnico Nacional, Prolongación de Carpio y Plan de Ayala s/n, Miguel Hidalgo, \\ Mexico City CP 11340, Mexico \\ 2 Instituto Nacional de Investigaciones Forestales, Agrícolas y Pecuarias, Campo Experimental Pabellón, \\ Km. 32.5 Carr. Ags.-Zac., Pabellón de Arteaga, Ags. CP 20660, Mexico \\ * Correspondence: capotezu@hotmail.com; Tel.: +52-555-729-6000 (ext. 62418)
}

Received: 29 May 2019; Accepted: 3 July 2019; Published: 17 August 2019

check for updates

\begin{abstract}
Bark beetles commonly produce de novo terpenoid pheromones using precursors synthesized through the mevalonate pathway. This process is regulated by Juvenile Hormone III (JH III). In this work, the expression levels of mevalonate pathway genes were quantified after phloem feeding - to induce the endogenous synthesis of JH III-and after the topical application of a JH III solution. The mevalonate pathway genes from D. rhizophagus were cloned, molecularly characterized, and their expression levels were quantified. Also, the terpenoid compounds produced in the gut were identified and quantified by Gas Chromatography Mass Spectrometry (GC-MS). The feeding treatment produced an evident upregulation, mainly in acetoacetyl-CoA thiolase $(A A C T)$, 3-hydroxy-3-methylglutaryl-CoA synthase (HMGS), 3-hydroxy-3-methylglutaryl-CoA reductase $(H M G R)$, phosphomevalonate kinase $(P M K)$, and isopentenyl diphosphate isomerase (IPPI) genes, and males reached higher expression levels compared to females. In contrast, the JH III treatment did not present a clear pattern of upregulation in any sex or time. Notably, the genes responsible for the synthesis of frontalin and ipsdienol precursors (geranyl diphosphate synthase/farnesyl diphosphate synthase (GPPS/FPPS) and geranylgeranyl diphosphate synthase (GGPPS)) were not clearly upregulated, nor were these compounds further identified. Furthermore, trans-verbenol and myrtenol were the most abundant compounds in the gut, which are derived from an $\alpha$-pinene transformation rather than de novo synthesis. Hence, the expression of mevalonate pathway genes in D. rhizophagus gut is not directed to the production of terpenoid pheromones, regardless of their frequent occurrence in the genus Dendroctonus.
\end{abstract}

Keywords: mevalonate pathway; Dendroctonus; juvenile hormone III; pheromone production

\section{Introduction}

Dendroctonus bark beetles (Curculionidae: Scolytinae) are key ecological agents of coniferous forests, and some of their species are the most destructive pests in these communities in North and Central America [1,2]. These bark beetles complete their life cycles under the bark of host trees, except for a brief dispersal period during which adults find a new host and mate. These insects locate and colonize their host trees through the detection of specific blends of terpenoid compounds (kairomones) 
produced by the trees, as well as aggregation and antiaggregation pheromones [3,4]. Aggregation pheromones are essential either as sex attractants or as coordinators of massive attacks against the hosts, whereas antiaggregation pheromones regulate the population of conspecifics that can settle on the trees [5].

Pheromone production in bark beetles, including the Dendroctonus species, is an adaptive strategy favored by natural selection because pheromones provide information about food availability and sources, conspecific attraction, reproductive partners, and regulation of population density [6]. In these insects, pheromone production has several ecological sources, such as microbial assisted synthesis [7], autoxidation of host compounds [8], sequestration and release of host compounds [9], transformation of host terpenes to pheromonal compounds [10], and endogenous production [4,11-15]. Pheromone production can vary based on insect health, mating system, colonization strategy, species aggressiveness, and geographical region [16-19].

The mevalonate (MVA) pathway is an endogenous metabolic route present in eukaryotes, archaea, and some eubacteria. This route is directly involved in the synthesis of cholesterol, hormones, and other isoprenoids metabolites [20-22]. Hemi- and monoisoprenoids compounds, as well as bicyclic acetals used as aggregation or antiaggregation pheromones by bark beetles, are produced through de novo synthesis in the gut of these insects [4,23-28]. Although it is not known how the MVA pathway is regulated in bark beetles, it has been demonstrated that feeding on phloem triggers the synthesis of Juvenile Hormone III (JH III) in the corpora allata [29], thereby regulating transcription of the genes coding for the enzymes that catalyze the synthesis of terpenoid backbones ( $A A C T$, acetoacetyl-CoA thiolase; HMGS, 3-hydroxy-3-methylglutaryl-CoA synthase; HMGR, 3-hydroxy-3-methylglutaryl-CoA reductase; $M K$, mevalonate kinase; $P M K$, phosphomevalonate kinase; $M D P C$, diphosphomevalonate decarboxylase; IPPI, isopentenyl diphosphate isomerase; GPPS, geranyl diphosphate synthase; FPPS, farnesyl diphosphate synthase; GGPPS, geranylgeranyl diphosphate synthase) [30,31].

Most of these enzymes synthesize a unique product, except for GPPS and FPPS, which can be mono- or bifunctional (GPPS/FPPS) [32], as reported in Phaedon cochleariae [33], Manduca sexta [34], Myzus persicae [35], and Dendroctonus ponderosae [36].

Dendroctonus rhizophagus Thomas and Bright is an endemic species of the Sierra Madre Occidental in Mexico and an atypical species within the Dendroctonus genus because generally just one or two pairs, rather than tens to thousands of pairs, colonize and kill a single host of seedlings or saplings $<3.0 \mathrm{~m}$ high and $<20 \mathrm{~cm}$ in diameter of 11 pine species (Pinales, Pinaceae), mainly Pinus arizonica Engelm., P. engelmannii Carr., P. leiophylla Schlecht and Cham, and P. durangensis Martínez [37,38]. The life cycle of this bark beetle is univoltine and synchronous. Females lay their eggs in groups, and when larvae hatch, they feed gregariously on the phloem of the tree stem. During winter, larvae remain in the roots to survive the low temperatures, and in early spring, they regroup in the primary roots to transform into pupae and adults. Females and males emerge in the early summer to colonize a new host and mate [39]. Chemical ecology studies in D. rhizophagus have reported high levels of trans-verbenol, as well as other oxygenated monoterpenes, such as myrtenal, myrtenol, cis-verbenol, fenchyl alcohol, and verbenone, but not frontalin or ipsdienol [40]. Whereas ipsdienol has only been identified in D. mesoamericanus [41], frontalin is one of the main pheromones identified in most Dendroctonus species [42], such as in D. frontalis [43], D. ponderosae [44,45], D. mesoamericanus [41], and D. valens [46]. This last species is the D. rhizophagus sibling species, and both coexist in Mexico, performing their life cycle in many places without interfering with each other, since their colonization strategies and host preferences are different.

Several in vitro assays have documented that the feeding and topical application of JH III in some bark beetle species-such as Ips confusus, Ips pini [47], Dendroctonus armandi [48] and Dendroctonus jeffreyi [24,49]—increases the transcription levels from the MVA pathway genes, and in some cases, it also induces the production of ipsdienol or frontalin in the midgut tissue [24-26]. Because frontalin and ipsdienol were not previously identified in the gut of D. rhizophagus [40], we evaluated the potential for the de novo synthesis of frontalin and ipsdienol in pre-emerged adults 
of this species after phloem feeding and topical exposure to JH III. For this purpose, MVA pathway genes were cloned, molecularly characterized, and their relative expression was measured. In addition, we identified and quantified by Gas Chromatography Mass Spectrometry (GC-MS) the compounds present in the gut of fed males and females of D. rhizophagus.

\section{Results}

\subsection{Identification of MVA Pathway Genes and Phylogenetic Analysis}

The highest similarity percentages of all MVA pathway genes from D. rhizophagus were found with the sequences from $D$. ponderosae followed by other Dendroctonus species. The MK gene had the lowest nucleotidic (83\%) and aminoacidic (69.8\%) similarities, whereas HMGR (nt 96\%) and AACT (aa 97.6\%) had the highest. The similarities obtained with other coleopterans-like Tribolium castaneum and Leptinotarsa decemlineata - were on average $70 \%$ for nucleotides and $69 \%$ for amino acids (Table 1 ). In general, $M K$ was the most variable of all MVA pathway genes.

Table 1. Nucleotidic and aminoacidic similarities from mevalonate (MVA) pathway sequences isolated from D. rhizophagus compared with previously reported Dendroctonus species and other coleopteran sequences. (NCBI, National Center of Biotechnology Information).

\begin{tabular}{|c|c|c|c|c|c|}
\hline Gene & Species & $\begin{array}{c}\text { Blast NCBI } \\
\text { GenBank No. }\end{array}$ & $\%$ Similarity & $\begin{array}{c}\text { Blast UniProt } \\
\text { UniProt No. }\end{array}$ & $\%$ Similarity \\
\hline \multirow{4}{*}{$A A C T$} & Dendroctonus ponderosae & JQ855638.1 & 93 & I1VJ17 & 97.6 \\
\hline & Dendroctonus jeffreyi & AY966010.1 & 92 & Q56CY6 & 91.5 \\
\hline & Leptinotarsa decemlineata & KP689334.1 & 72 & A0Ä0H4IRH6 & 81.1 \\
\hline & Tribolium castaneum & XM_969915.4 & 72 & D6WAN7 & 79.9 \\
\hline \multirow{6}{*}{ HMGS } & Dendroctonus ponderosae & JQ855690.1 & 95 & I1VJ69 & 96.7 \\
\hline & Dendroctonus jeffreyi & AF166002.1 & 94 & Q9NDA8 & 93.7 \\
\hline & Dendroctonus armandi & KP317812.1 & 92 & A0A0F7LEZ1 & 94.5 \\
\hline & Ips pini & AY902193.1 & 72 & Q5EE42 & 75.9 \\
\hline & Leptinotarsa decemlineata & KР689335.1 & 71 & A0A0H4J592 & 67.6 \\
\hline & Tribolium castaneum & XM_968344.4 & 71 & D6WTE1 & 65.9 \\
\hline \multirow{7}{*}{ HMGR } & Dendroctonus ponderosae & KF444677.1 & 96 & $\mathrm{U} 5 \mathrm{ZZ40}$ & 96.8 \\
\hline & Dendroctonus jeffreyi & AF159136.1 & 95 & Q9N6G8 & 96.3 \\
\hline & Dendroctonus armandi & KP317811.1 & 93 & A0A0F7LG51 & 95.4 \\
\hline & Ips paraconfusus & AF071750.2 & 75 & Q9XY99 & 78.5 \\
\hline & Ips pini & AF304440.1 & 74 & Q95WT1 & 78.1 \\
\hline & Leptinotarsa decemlineata & KP689337.1 & 72 & A0A0H4ISG3 & 66.6 \\
\hline & Tribolium castaneum & XM_008195109.2 & 69 & A0A139WIA9 & 68.3 \\
\hline \multirow{2}{*}{$M K$} & Dendroctonus ponderosae & JQ855693.1 & 83 & I1VJ72 & 69.8 \\
\hline & Leptinotarsa decemlineata & КР689338.1 & - & A0A0H4IUW0 & 41.8 \\
\hline \multirow{2}{*}{$P M K$} & Dendroctonus ponderosae & JQ855702.1 & 91 & I1VJ81 & 89.1 \\
\hline & Leptinotarsa decemlineata & КР689339.1 & 68 & A0A0H4IRI1 & 59.2 \\
\hline \multirow{3}{*}{$M D P C$} & Dendroctonus ponderosae & JQ855692.1 & 93 & I1VJ71 & 92 \\
\hline & Leptinotarsa decemlineata & KР689340.1 & 68 & A0A0H4J596 & 61.6 \\
\hline & Tribolium castaneum & XM_008192276.2 & 66 & D6WE42 & 64.4 \\
\hline \multirow{5}{*}{$I P P I$} & Dendroctonus ponderosae & JQ855691.1 & 94 & I1VJ70 & 92.9 \\
\hline & Dendroctonus jeffreyi & AY966011.1 & 94 & Q56CY5 & 92.9 \\
\hline & Dendroctonus armandi & KT784804.1 & 86 & A0A0N9H5S7 & 89.6 \\
\hline & Leptinotarsa decemlineata & KP689341.1 & 71 & A0A0H4IVW7 & 70.1 \\
\hline & Tribolium castanem & XM_966431.3 & 65 & D6WP58 & 76.6 \\
\hline \multirow{6}{*}{ GPPS/FPPS } & Dendroctonus ponderosae & JQ855705.1 & 95 & I1VJ84 & 96.3 \\
\hline & Dendroctonus jeffreyi & AY966009.1 & 94 & Q56CY7 & 94.9 \\
\hline & Dendroctonus armandi & KR140284.1 & 93 & A0A0N9EI79 & 96 \\
\hline & Ips pini & AY953507.1 & 72 & Q58GE9 & 72.1 \\
\hline & Tribolium castanem & NM_001170618.1 & 70 & D6WSE5 & 70.4 \\
\hline & Leptinotarsa decemlineata & КР 689343.1 & 66 & A0A0H4IUW5 & 55.5 \\
\hline \multirow{4}{*}{ GGPPS } & Dendroctonus ponderosae & JQ855707.1 & 94 & I1VJ86 & 95.3 \\
\hline & Dendroctonus frontalis & GAFI01012895.1 & 93 & T1DSZ4 & 94.6 \\
\hline & Leptinotarsa decemlineata & KP689342.1 & 72 & A0A0H4ISG7 & 75.7 \\
\hline & Tribolium castaneum & XM_966351.3 & 71 & D6WD18 & 68.3 \\
\hline
\end{tabular}

- No significant similarity found. 
The phylogeny of each of the MVA pathway enzymes of $D$. rhizophagus demonstrated that they integrate consistent groups (Bootstrap values $>63 \%$ ) with the corresponding enzymes of other Dendroctonus species. Slight differences between species of this genus are attributable to synonym substitutions that occur mostly in the third position of some triplet codons, but not within or around the motif of each enzyme. Similarly, Dendroctonus spp. enzymes are different from those of other bark beetles (e.g., Ips) and weevils (e.g., Pissodes), but in general, all Coleopterans integrated into a consistent group different from other insect groups in the trees of each protein (Bootstrap values $>63 \%$ ) (Figure 1 ).
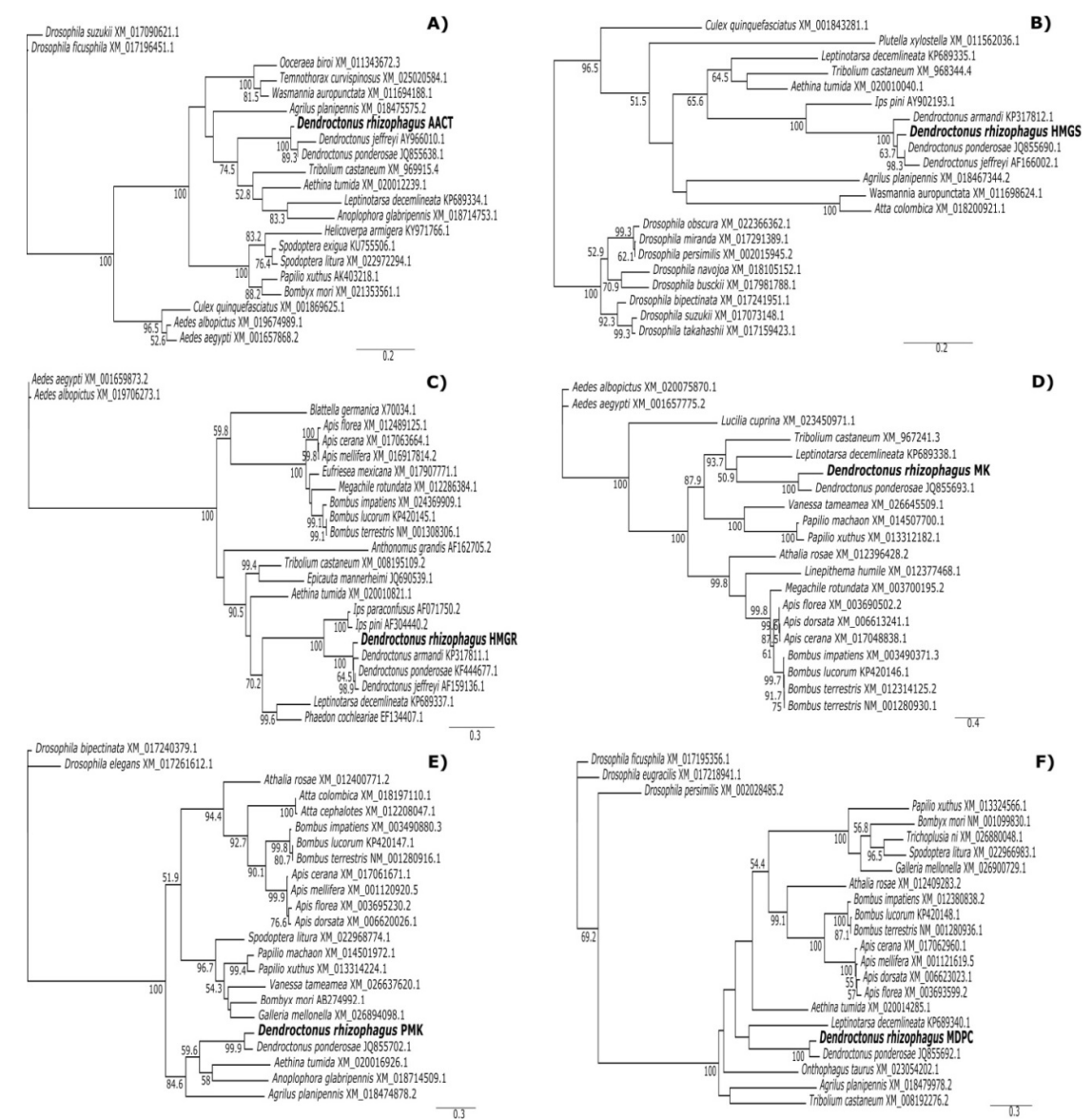

D)
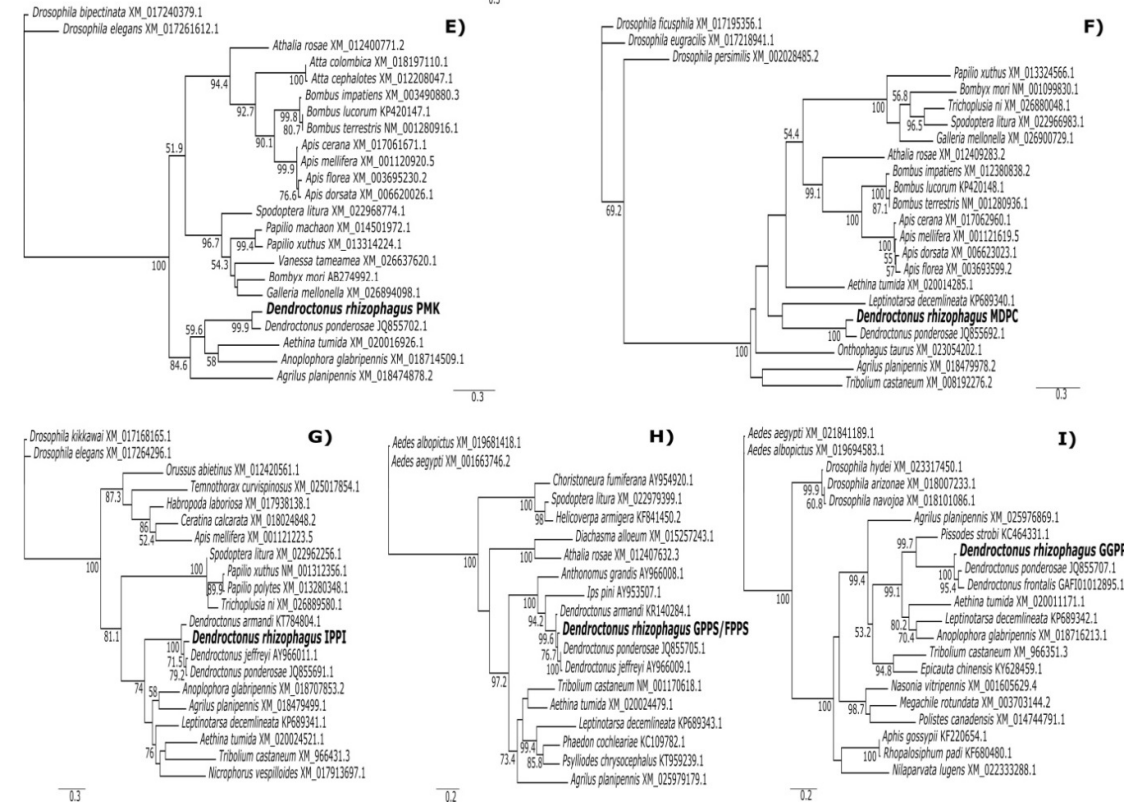

Figure 1. Maximum likelihood trees of MVA pathway genes based on the amino acid sequences of D. rhizophagus along with insect sequences obtained from GenBank. Bootstrap values after 1000 replicates are shown at nodes. (C) HMGR used the model JTT $(+\mathrm{G}+\mathrm{I}+\mathrm{F})$ with an estimated proportion of invariable sites (I) of 0.073 and a gamma parameter $(\mathrm{G})$ of $0.575(-\ln L=14615.13)$. (A) AACT $(\mathrm{I}=0.230$, $\mathrm{G}=0.929,-\ln \mathrm{L}=5343.20) ;(\mathrm{B}) \mathrm{HMGS}(\mathrm{I}=0.242, \mathrm{G}=1.166,-\ln \mathrm{L}=6933.67)$; (D) $\mathrm{MK}(\mathrm{I}=0.075$, $\mathrm{G}=1.464,-\operatorname{lnL}=9730.43) ;(\mathrm{F}) \mathrm{MDPC}(\mathrm{I}=0.221, \mathrm{G}=1.139,-\operatorname{lnL}=8370.35) ;(\mathrm{H}) \mathrm{GPPS} / \mathrm{FPPS}(\mathrm{I}=0.068$, $\mathrm{G}=1.253,-\ln \mathrm{L}=8378.21)$; and $(\mathrm{I}) \mathrm{GGPPS}(\mathrm{I}=0.253, \mathrm{G}=1.001,-\ln \mathrm{L}=5004.36)$ used the model LG $(+\mathrm{G}+\mathrm{I}+\mathrm{F})$; however, $(\mathrm{G}) \mathrm{IPPI}(\mathrm{I}=0.150, \mathrm{G}=1.240,-\ln \mathrm{L}=5622.99)$ and $(\mathrm{E}) \mathrm{PMK}(\mathrm{I}=0.160, \mathrm{G}=1.459$, $-\ln L=3924.98)$ used the model LG $(+G+I)$. 


\subsection{Molecular Characterization of MVA Pathway Genes}

The full-length ORF of putative MVA pathway genes varied from 558 to $2550 \mathrm{bp}$ encoding 185 to 849 amino acids. Among the predictions of physicochemical properties (Table 2), the M.W. ranged from 21.3 to $93.4 \mathrm{kDa}$, and $\mathrm{pI}$ ranged from 6.04 to 8.7. According to the subcellular localization predictions, the MVA pathway's putative proteins can be in the mitochondria, in the cytoplasm, in the endoplasmic reticulum membrane, in the peroxisome, or extracellular (Table 2). Regarding the secondary structure, five transmembrane helices were determined in the HMGR putative protein. The $\alpha$-helices and $\beta$-sheets numbers predicted for each putative protein were different. The number of $\alpha$-helices varied from 8 (PMK and IPPI) to 16 (HMGR and GPPS/FPPS), whereas the $\beta$-sheets varied from 2 (GPPS/FPPS and GGPPS) to 17 (HMGS and MDPC) (Table 2; Figures S1-S9).

Table 2. Physicochemical properties, cellular localization, and secondary structure elements predicted for D. rhizophagus MVA pathway's putative proteins.

\begin{tabular}{|c|c|c|c|c|c|c|c|c|c|}
\hline \multirow{2}{*}{ Protein } & \multirow{2}{*}{$\begin{array}{c}\mathrm{ORF}^{1}(\mathrm{bp}) \\
\text { Accession No. }\end{array}$} & \multirow{2}{*}{$\mathrm{Aa}^{2}$} & \multirow{2}{*}{$\begin{array}{l}\text { M.W. } \\
\text { (kDa) }\end{array}$} & \multirow{2}{*}{$\mathrm{pI}^{3}$} & \multicolumn{2}{|c|}{ Subcellular Localization Predictions } & \multicolumn{3}{|c|}{ Secondary Structure Elements } \\
\hline & & & & & TargetP & ProtComp 9.0 & TMH $^{5}$ & $\alpha-\mathrm{H}^{6}$ & $\beta-S^{6}$ \\
\hline AACT & $\begin{array}{c}1239 \\
\text { MK387135 }\end{array}$ & 412 & 43.2 & 8.64 & $\begin{array}{c}0.458 \mathrm{mTP}^{4}, 0.036 \mathrm{SP}^{4} \\
0.441 \text { Other }\end{array}$ & Mitochondrial & No TMH & 11 & 16 \\
\hline HMGS & $\begin{array}{c}1374 \\
\text { MK387139 }\end{array}$ & 457 & 50.7 & 6.04 & $\begin{array}{c}0.017 \mathrm{mTP}, 0.643 \mathrm{SP} \\
0.648 \text { Other }\end{array}$ & Cytoplasmic & No TMH & 15 & 17 \\
\hline HMGR & $\begin{array}{c}2550 \\
\text { MK387137 }\end{array}$ & 849 & 93.4 & 8.07 & $\begin{array}{l}0.124 \mathrm{mTP}, 0.471 \mathrm{SP}, \\
0.398 \text { Other }\end{array}$ & $\begin{array}{l}\text { Membrane bound } \\
\text { Endoplasmic } \\
\text { Reticulum }\end{array}$ & $5 \mathrm{TMH}$ & 16 & 11 \\
\hline MK & $\begin{array}{c}1308 \\
\text { MK387142 }\end{array}$ & 435 & 48.3 & 6.17 & $\begin{array}{c}0.497 \mathrm{mTP}, 0.046 \mathrm{SP}, \\
0.579 \text { Other }\end{array}$ & Cytoplasmic & No TMH & 11 & 13 \\
\hline PMK & $\begin{array}{c}558 \\
\text { MK387143 }\end{array}$ & 185 & 21.3 & 6.89 & $\begin{array}{c}0.092 \mathrm{mTP}, 0.077 \mathrm{SP} \\
0.881 \text { Other }\end{array}$ & Peroxisomal & No TMH & 8 & 5 \\
\hline MDPC & $\begin{array}{c}1161 \\
\text { MK387140 }\end{array}$ & 386 & 42.9 & 7.01 & $\begin{array}{c}0.058 \mathrm{mTP}, 0.275 \mathrm{SP}, \\
0.748 \text { Other }\end{array}$ & Extracellular & No TMH & 11 & 17 \\
\hline GPPS/FPPS & $\begin{array}{c}1290 \\
\text { MK387138 }\end{array}$ & 429 & 49.5 & 8.7 & $\begin{array}{c}0.778 \mathrm{mTP}, 0.063 \mathrm{SP}, \\
0.223 \text { Other }\end{array}$ & $\begin{array}{l}\text { Cytoplasmic/ } \\
\text { Mitochondrial }\end{array}$ & No TMH & 16 & 2 \\
\hline GGPPS & $\begin{array}{c}894 \\
\text { MK387136 }\end{array}$ & 297 & 34.3 & 6.33 & $\begin{array}{c}0.108 \mathrm{mTP}, 0.091 \mathrm{SP} \\
0.855 \text { Other }\end{array}$ & Cytoplasmic & No TMH & 15 & 2 \\
\hline
\end{tabular}

${ }^{1}$ Open Reading Frame. ${ }^{2}$ Number of amino acids defined by the ExPASy Translate tool. ${ }^{3}$ Molecular Weight and Isoelectric point predicted with ProtParam. ${ }^{4}$ mTP: mitochondrial, SP: secretory pathway. ${ }^{5}$ Predicted number of transmembrane helices (TMH) by the TMHMM Server v. 2.0. ${ }^{6}$ Number of $\alpha$-helices $(\alpha-\mathrm{H})$ and $\beta$-sheets $(\beta$-S) assigned by the ESPript 3.0 program.

\subsection{Quantitative Real-Time Polymerase Chain Reaction (RT-qPCR)}

Fed males, solitary and in pairs, displayed higher expression levels than females in most genes, with the induction of gene expression being more evident in AACT, HMGS, HMGR, PMK, and IPPI genes. In the case of insects exposed to JH III, a limited effect in the induction of MVA pathway genes was observed, due to the lack of a clear pattern for any sex or time (Figure 2). Overall, our findings illustrated that the expression levels of fed insects were higher than those from insects stimulated with JH III for almost all MVA pathway genes.

Regarding the influence of the analyzed factors over expression levels (Tables S1-S4), statistically significant differences were found between sexes in all genes $(p<0.01)$, except for GGPPS. Whereas HMGS and HMGR genes showed significant differences only between sexes $(p<0.001)$, in the rest of the genes, these differences were also found in the other factors: time and condition. The feeding condition (solitary or paired) was not significant in the expression levels of the early genes (AACT, HMGS, HMGR), but it was for the MK, MDPC, IPPI, GPPS/FPPS, and GGPPS genes $(p<0.005)$. Time was only significant for the $A A C T, M K, P M K$, and GPPS/FPPS genes $(p<0.05)$. 

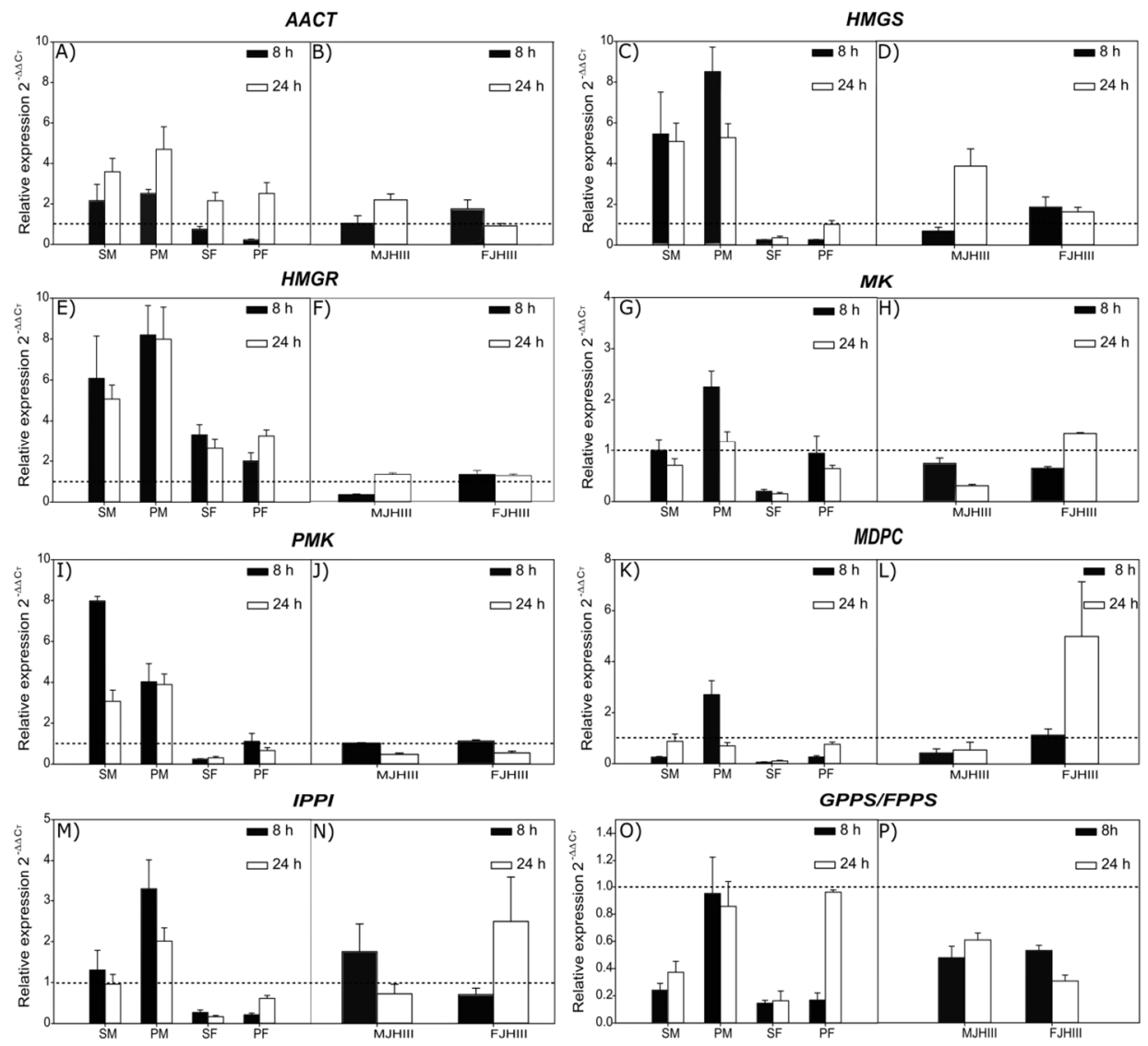

GGPPS

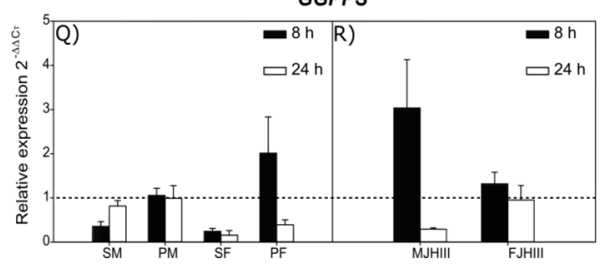

Figure 2. Relative expression of MVA pathway genes calculated by the $2^{-\Delta \Delta C t}$ method in D. rhizophagus pre-emerged adults fed on phloem $(\mathbf{A}, \mathbf{C}, \mathbf{E}, \mathbf{G}, \mathbf{I}, \mathbf{K}, \mathbf{M}, \mathbf{O}, \mathbf{Q})$ or treated with JH III $(\mathbf{B}, \mathbf{D}, \mathbf{F}, \mathbf{H}, \mathbf{J}, \mathbf{L}, \mathbf{N}, \mathbf{P}, \mathbf{R})$. SM: solitary males, PM: paired males, SF: solitary females, PF: paired females, MJHIII: males treated with JH III, FJHIII: females treated with JH III. Control levels are indicated with the dashed lines; values $>1$ on the $y$-axis $\left(2^{-\Delta \Delta C t}\right)$ indicate upregulation.

\subsection{Quantification of Volatile Compounds}

Six oxygenated monoterpenes: fenchyl alcohol, cis-verbenol, trans-verbenol, myrtenal, myrtenol, and verbenone were identified from extracts of dissected guts of phloem-fed $D$. rhizophagus females and males, both in solitary or paired conditions, at 18, 24, and $43 \mathrm{~h}$. Higher quantities of oxygenated monoterpenes were recorded either at 18 or $24 \mathrm{~h}$ of feeding, whereas few compounds were detected at $43 \mathrm{~h}$ (Figure 3). The extracts of dissected guts from the unfed insects showed low quantities of some monoterpenes, while females presented fenchyl alcohol and verbenone. In males, traces of myrtenal, myrtenol, and verbenone were detected (Table 3).

Trans-verbenol and myrtenol were the oxygenated monoterpenes detected in higher quantities in fed insects. Myrtenol was the only compound detected in all treatments, sexes and times. The average quantity of this oxygenated monoterpene at 18 and $24 \mathrm{~h}$ varied between $256-323 \mathrm{ng} / \mathrm{beetle}$, except in paired females, where the value reached $127.5 \mathrm{ng} / \mathrm{beetle}$. The trans-verbenol quantities were higher than cis-verbenol ones ( $\approx 3$ times), with the latter being recorded only at 18 and $24 \mathrm{~h}$ in all 
treatments. Myrtenal was detected at the three feeding times in solitary females and paired males, but the highest quantities were recorded in paired females at $24 \mathrm{~h}$. Finally, fenchyl alcohol and verbenone were detected only at low quantities; the former was recorded at 24 and $43 \mathrm{~h}$ both in solitary and paired females, as well as in paired males, whereas verbenone was mainly detected at 18 and $24 \mathrm{~h}$ in all treatments (Figure 3).

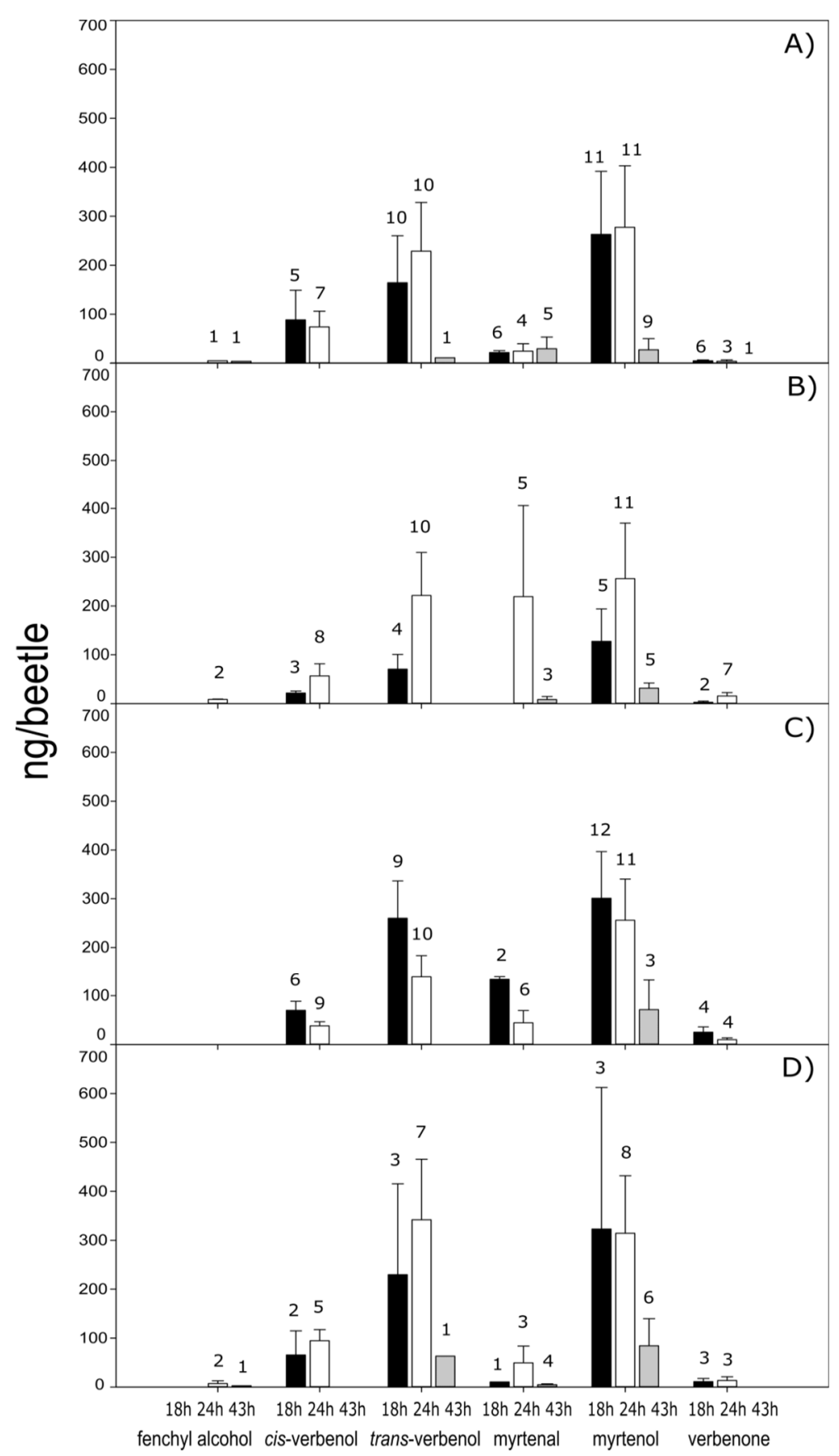

Figure 3. Quantities (mean $+\mathrm{SEM}$ ) of oxygenated monoterpenes detected in pre-emerged D. rhizophagus adults fed during 18, 24, and $43 \mathrm{~h}$ on the phloem of Pinus leiophylla. (A) solitary females, (B) females paired with males, (C) solitary males, (D) males paired with females. Numbers above each bar correspond to the number of insects in which the compound was detected out of a maximum of 12 adults tested. 
Table 3. The range of oxygenated monoterpenes quantities (ng/beetle) extracted from the gut of pre-emerged unfed D. rhizophagus.

\begin{tabular}{ccc}
\hline Compound & Female & Male \\
\hline \multirow{2}{*}{ fenchyl alcohol } & $0.01-0.04^{1}$ & - \\
& $2 / 12^{2}$ & $0 / 12$ \\
\hline \multirow{2}{*}{ cis-verbenol } & - & - \\
& $0 / 12$ & $0 / 12$ \\
\hline \multirow{2}{*}{ trans-verbenol } & - & - \\
& $0 / 12$ & $0 / 12$ \\
\hline \multirow{2}{*}{ myrtenal } & - & 0.007 \\
& $0 / 12$ & $1 / 12$ \\
\hline \multirow{2}{*}{ myrtenol } & - & $0.03-0.1$ \\
& $0 / 12$ & $3 / 12$ \\
\hline \multirow{2}{*}{ verbenone } & $0.002-0.003$ & $0.002-0.05$ \\
& $2 / 12$ & $3 / 12$ \\
\hline
\end{tabular}

${ }^{1}$ Quantity range (ng/beetle). ${ }^{2}$ Ratio between number of insects in which the compound was detected and the total number of insects tested.

\section{Discussion}

The phylogenetic analyses of MVA pathway enzymes in D. rhizophagus produced well supported topologies (bootstrap values $>63 \%$ ), suggesting the monophyly of these enzymes in Dendroctonus species. Phylogenies also showed a general topology congruent with the integrity of taxonomical groups (Figure 1). Despite the low number of sequences of these enzymes available in different databases, the integration of consistent monophyletic groups in each MVA pathway enzyme of Dendroctonus spp. suggests that their functions and biochemical characteristics are conserved. In fact, many mutational changes observed in the sequences of genes occurred in the third position of the codons, as suggested by the high frequency of synonym mutations in amino acids located outside the catalytic region.

The in silico analysis suggested subcellular localizations for all MVA pathway enzymes in D. rhizophagus, which partially agrees with those known for other insect or mammal species (Table 2). For example, the mitochondrial prediction of the AACT enzyme in D. rhizophagus has also been reported as mitochondrial in human [50], but as cytosolic in Ostrinia scapulalis [51]. The HMGS enzyme, inferred as cytoplasmic in D. rhizophagus, has been recorded as mitochondrial and cytosolic in humans [52] and rats [53], and as cytosolic in German cockroach, Blattella germanica [54] and the Pacific beetle cockroach, Diploptera punctata [55]. The HMGR, predicted as an enzyme of the endoplasmic reticulum membrane in D. rhizophagus, has also been reported in the same site in mammals [56,57] and insects [58]. The prediction for MK, PMK and MDPC enzymes in D. rhizophagus agree with the cytosolic location $[59,60]$ or in peroxisomes [61,62] reported in insects and humans. Lastly, the mitochondrial and cytoplasmic predictions for GPPS/FPPS and GGPPS enzymes in this bark beetle were in concordance with the findings for these enzymes in mammals [63,64] and Drosophila melanogaster [65]. The IPPI enzyme of $D$. rhizophagus was the only protein whose predicted location (cytoplasmic) disagrees with those reported in mammals (peroxisomes) [66].

The expression analysis showed that phloem feeding and JH III topical application differentially induced several MVA pathway genes in D. rhizophagus (Figure 2). Most genes reached higher expression levels in fed rather than stimulated insects, with solitary and paired males showing the highest levels in almost all genes. These findings agree with previous reports on the expression of these genes in bark beetles, which demonstrated that MVA pathway genes presented higher upregulation levels in males than females in the majority of analyzed genes. In addition, male genes are continuously reported as upregulated, whereas female gene expression can be upregulated, downregulated or remain at basal levels (Table 4). With respect to MVA pathway genes in JH III stimulated insects, an irregular 
expression pattern was displayed, and there was no tendency for a specific sex or time (Figure 2). However, other studies in bark beetles have reported that JH III induced some of these genes, showing high expression levels mainly in males, or at least higher compared to females $[25,27,28,48,67,68]$.

Upregulation was observed mainly in the AACT, HMGS, HMGR, and PMK genes in fed males of $D$. rhizophagus in both conditions (solitary and paired) and both times. Females only exhibited upregulation in $A A C T$ at $24 \mathrm{~h}$. The HMGR gene, whose corresponding enzyme synthesizes mevalonate, was the only gene that exhibited upregulation in both fed males and females at both times and conditions (solitary or paired). HMGR is a highly regulated enzyme [69], and its gene is one of the most studied in bark beetles, together with HMGS.

Table 4. Previous reports of relative expression analysis of bark beetle MVA pathway genes after feeding on phloem or JH III treatments.

\begin{tabular}{|c|c|c|c|c|c|c|}
\hline Gene & Species & Male & Female & Technique & Treatment & Reference \\
\hline \multirow{2}{*}{$A A C T$} & I. pini & $\mathrm{U}$ & $\mathbf{U}^{*}$ & RT-qPCR & Feeding & [32] \\
\hline & I. pini & $\mathrm{C}$ & $\mathbf{U}^{*}$ & RT-qPCR & JH III & [70] \\
\hline \multirow{8}{*}{$H M G S$} & I. pini & $\mathrm{U}$ & $\mathbf{U}^{*}$ & RT-qPCR & Feeding & [32] \\
\hline & I. pini & $\mathrm{U}$ & $\mathrm{U}$ & RT-qPCR & JH III & [70] \\
\hline & I. pini & $\mathrm{U}^{*}$ & $\mathrm{U}$ & RT-qPCR & JH III & [67] \\
\hline & D. jeffreyi & $\mathrm{U}^{*}$ & $\mathrm{C}$ & Northern blot & JH III & [27] \\
\hline & D. armandi & $U^{*}$ & $\mathrm{U}$ & RT-qPCR & Feeding & [48] \\
\hline & D. armandi & $\mathrm{U}^{*}$ & $\mathrm{C}$ & RT-qPCR & JH III & [48] \\
\hline & I. confusus & $\mathrm{U}$ & NR & RT-qPCR & Feeding & [47] \\
\hline & I. confusus & $\mathrm{U}$ & NR & RT-qPCR & JH III & {$[47]$} \\
\hline \multirow{10}{*}{$H M G R$} & I. paraconfusus & $\mathrm{U}^{*}$ & $\mathrm{U}$ & Northern blot & JH III & [68] \\
\hline & I. pini & $U^{*}$ & $\mathrm{U}$ & Northern blot & JH III & [25] \\
\hline & I. pini & $\mathrm{U}$ & $\mathbf{U}^{*}$ & RT-qPCR & Feeding & [32] \\
\hline & I. pini & $\mathrm{U}$ & $\mathbf{U}^{*}$ & RT-qPCR & JH III & [70] \\
\hline & I. confusus & $\mathrm{U}$ & NR & RT-qPCR & Feeding & [47] \\
\hline & I. confusus & $\mathrm{U}$ & NR & RT-qPCR & JH III & [47] \\
\hline & D. jeffreyi & $\mathrm{U}^{*}$ & $\mathrm{C}$ & Northern blot & JH III & [28] \\
\hline & D. ponderosae & $\mathrm{U}^{*}$ & $\mathrm{U}$ & RT-qPCR & Feeding & [71] \\
\hline & D. armandi & $U^{*}$ & $\mathrm{U}$ & RT-qPCR & Feeding & [48] \\
\hline & D. armandi & $\mathrm{U}^{*}$ & $\mathrm{C}$ & RT-qPCR & JH III & [48] \\
\hline$M K$ & I. pini & $\mathrm{U}^{*}$ & C & RT-qPCR & JH III & [70] \\
\hline \multirow{2}{*}{$M D P C$} & I. pini & $\mathrm{U}^{*}$ & $\mathrm{U}$ & RT-qPCR & Feeding & [32] \\
\hline & I. pini & $\mathrm{U}$ & $\mathbf{U}^{*}$ & RT-qPCR & JH III & [70] \\
\hline \multirow{2}{*}{$I P P I$} & I. pini & $\mathrm{U}$ & $\mathbf{U}^{*}$ & RT-qPCR & Feeding & [32] \\
\hline & I. pini & $\mathrm{U}$ & $\mathbf{U}^{*}$ & RT-qPCR & JH III & [70] \\
\hline \multirow{7}{*}{ GPPS/FPPS } & GPPS I. pini & $\mathrm{U}^{*}$ & $\mathrm{D}$ & RT-qPCR & Feeding & [32] \\
\hline & GPPS I. pini & $\mathrm{U}$ & $\mathbf{U}^{*}$ & RT-qPCR & JH III & [70] \\
\hline & FPPS I. pini & $\mathrm{U}^{*}$ & $\mathrm{D}$ & RT-qPCR & Feeding & [32] \\
\hline & FPPS I. pini & $\mathrm{U}^{*}$ & D & RT-qPCR & JH III & [70] \\
\hline & D. ponderosae & $\mathrm{U}^{*}$ & $\mathrm{C}$ & RT-qPCR & Feeding & [36] \\
\hline & GPPS I. confusus & $\mathrm{U}$ & NR & RT-qPCR & Feeding & [47] \\
\hline & GPPS I. confusus & $\mathrm{U}$ & NR & RT-qPCR & JH III & [47] \\
\hline GGPPS & D. ponderosae & $\mathrm{U}^{*}$ & $\mathrm{C}$ & RT-qPCR & Feeding & [71] \\
\hline
\end{tabular}

U: Upregulated (U*: Sex with the highest expression levels) D: Downregulated C: Control level NR: Not reported.

These last genes achieved similar expression levels in $D$. armandi males both in phloem-fed insects and JH III stimulated insects [48], but in I. confusus, both genes reached higher expression levels in phloem-fed insects than in stimulated insects. In contrast to what was observed in fed insects, neither the enzymatic activity of HMGS, HMGR, and GPPS nor pheromone production was recorded in the $\mathrm{JH}$ III stimulated insects of I. confusus. It has been hypothesized that the deficiency of pheromone 
production in JH III stimulated insects might be due to the absence of a brain hormone that is only induced by feeding [47]. However, this might also be caused by the presence of a regulatory mechanism mediated by an AMP-activated protein kinase (AMPK) analog to that reported in mammals, in which HMGR enzymatic activity is regulated according to the available energy. A high AMP:ATP ratio induces HMGR phosphorylation by AMPK, which inhibits the enzyme [72]. An analog strategy has been reported in yeasts, where the enzyme is inactivated when the available energy is low [73]. These strategies were presumably developed by convergent evolution and might also be present in insects, whose regulation mechanisms are not yet known [72].

The upregulation of MDPC and IPPI genes observed in paired fed males in both times, as well as in JH III stimulated males at $8 \mathrm{~h}$ and females at $24 \mathrm{~h}$, suggests that the synthesis of isopentenyl diphosphate (IPP) and dimethylallyl diphosphate (DMAPP) might occur in the gut of D. rhizophagus. Nevertheless, whereas both IPP and DMAPP are essential for the de novo production of frontalin or ipsdienol, the expression of GPPS/FPPS and GGPPS genes recorded in this bark beetle does not reflect the potential for de novo production of these compounds because they do not show a sex-specific expression pattern, nor do they exhibit sustained upregulation over time. Nevertheless, the basal activity of GPPS/FPPS and GGPPS might still allow the synthesis of terpenoid metabolites involved in basic cellular functions, e.g., protein prenylation and glycosylation (dolichols), and the electron transport chain (ubiquinone) [74-76].

In those bark beetle species that produce frontalin and ipsdienol, the GPPS/FPPS and GGPPS genes have always been recorded as upregulated in males (Table 4). In I. pini and I. confusus, it was demonstrated that the GPPS gene is upregulated from 4 to $32 \mathrm{~h}$ in fed males [47], whereas it was downregulated in females [32]. The GPPS enzyme and the cytochromes CYP9T2 and CYP9T3 are involved in the final steps of the production of ipsdienol and ipsenol pheromones from myrcene by males of these species $[14,77,78]$. In Dendroctonus species, the final steps of frontalin synthesis have not been described, despite the fact that males or females of several species (e.g., D. ponderosae, D. jeffreyi, D. armandi) produce frontalin either as aggregation, antiaggregation, or sexual pheromone $[23,44,49,79]$. In particular, it has been reported that the GGPPS gene is upregulated from 8 to $72 \mathrm{~h}$ in D. ponderosae males, which produce frontalin after phloem feeding, allowing us to hypothesize that the enzyme of this gene, together with cytochrome P450 enzymes, are involved in frontalin production through an undetermined mechanism [36,71].

Until now, it has been assumed that the upregulation of MVA pathway genes in the gut of bark beetles is directly involved in the synthesis of frontalin or ipsdienol. However, regardless of the observed upregulation of several genes in D. rhizophagus, our GC-MS analysis did not detect the presence of frontalin or ipsdienol pheromones. This result corresponds with previous findings in the same species from pre-emerged males and females forced to feed on host tissue in the laboratory, as well as in individuals collected from naturally attacked hosts at different stages of colonization [40].

It has been suggested that the endogenous production of sexual and aggregation pheromones in bark beetles is not necessarily a fundamental physiological process [18], such is the case of inbreeding species as Dendroctonus micans [80], D. punctatus [81], and presumably D. murrayanae [82,83], where females are fertilized by their siblings prior to emergence. Field observations of D. rhizophagus females ovipositing in galleries without a male partner, as well as the presence of sperm in the oviduct of non-emerged females [84], suggest that pheromone production might not be necessary in this species for host colonization and mating. Further studies are needed to expand our understanding of the D. rhizophagus mating system. However, the lack of frontalin may explain why D. rhizophagus does not interfere with its sibling species D. valens in the areas where they coexist in Mexico [85], as they present individual colonization strategies in which $D$. valens uses frontalin both as a sexual and an aggregation pheromone [46], as opposed to D. rhizophagus. The lack of pheromone production by D. rhizophagus prevents the colonization of adult trees, which are instead colonized by D. valens, confining its attacks to pine regeneration. 
However, our GC-MS assays confirmed the abundance of volatile compounds previously identified in D. rhizophagus gut, such as trans-verbenol and myrtenol. In particular, trans-verbenol was the compound that generated the best electrophysiological response in conspecifics [40].

The production of trans-verbenol and myrtenol is not associated with the MVA pathway activity in insects. These oxygenated monoterpenes are produced from the transformation of the pinenes obtained by the insect through feeding [86,87], or from their accumulation during immature stages and release upon their emergence or colonization establishment [9]. It has been assumed that these compounds are byproducts of a detoxification metabolism of host monoterpenes rather than metabolites synthesized through any metabolic pathway [88]. In fact, recently in D. ponderosae, it was reported that trans-verbenol is a product of the hydroxylation of $(-)-\alpha$-pinene and (+)- $\alpha$-pinene performed by the action of cytochrome CYP6DE1 [10].

\section{Materials and Methods}

\subsection{Insect Collection}

On June 2016, pre-emerged unfed adults (fully-melanized brood adults present in dead trees colonized the previous year that are moving outwards from the host tree to emerge) were manually collected from the roots or stem base of P. leiophylla seedlings and saplings at Chavarría ( $23^{\circ} 38^{\prime} 01.90^{\prime \prime}$ W $105^{\circ} 36^{\prime} 00.18^{\prime \prime}$ ) and Mil Diez (N 23 $48^{\prime} 28.12^{\prime \prime}$ W $105^{\circ} 24^{\prime} 11.63^{\prime \prime}$ ) localities, Pueblo Nuevo municipality, Durango, Mexico. The insects were sexed according to the shape of the seventh abdominal tergite [89] and transported to the laboratory in Magenta ${ }^{\mathrm{TM}}$ vessels GA 7 (Magenta Corp, Sigma-Aldrich-Merck, Darmstadt, Germany) under dark conditions at $4{ }^{\circ} \mathrm{C}$.

\subsection{Treatments Aimed at Induction of MVA Pathway Genes}

To obtain cDNA for the amplification and cloning of MVA pathway genes, solitary females $(n=12)$ and males $(n=12)$, as well as pairs $\left(n=12 \%, o^{7}\right)$, were introduced separately into $5.0 \mathrm{~mm}$ depth and $6.0 \mathrm{~mm}$ diameter holes drilled in fresh logs of uninfested Pinus leiophylla to feed for $24 \mathrm{~h}$ (feeding treatment). In the case of couples, females were placed first into the holes and males were introduced $4 \mathrm{~h}$ later. Both sexes were confined inside the logs for $24 \mathrm{~h}$. The logs were stored at room temperature in dark conditions, and patches of stainless steel mesh were stapled over the drilled holes to prevent insects from escaping. In addition, females $(n=12)$ and males $(n=12)$ were exposed to JH III (Sigma-Aldrich-Merck, Darmstadt, Germany) by applying $6 \mu \mathrm{g}$ of this hormone dissolved in $0.5 \mu \mathrm{L}$ of acetone over the ventral area of the abdomen (JH III treatment) with a Hamilton $5 \mu \mathrm{L}$ syringe (Hamilton Company, Reno, NV, USA) $[24,25,28]$. Each insect was placed individually in a $1.5 \mathrm{~mL}$ microcentrifuge tube and incubated for $24 \mathrm{~h}$ at room temperature in the dark.

\subsection{Total RNA Isolation and cDNA Synthesis}

Six insects of each group from both the fed and JH III treated insects were dissected, in order to obtain the complete alimentary canal. For insects fed in pairs $\left(q, o^{7}\right)$, each sex was processed individually. The tissues of each group were pooled and macerated in TRI Reagent ${ }^{\circledR}$ Solution (Ambion ${ }^{\mathrm{TM}}$, Thermo Fisher Scientific, Waltham, MA, USA), frozen in liquid nitrogen, and kept at $-80{ }^{\circ} \mathrm{C}$ until being processed with the RiboPure ${ }^{\mathrm{TM}}$ RNA Purification Kit (Ambion ${ }^{\mathrm{TM}}$ Thermo Fisher Scientific) according to the manufacturer's protocol. RNA concentration and purity $\left(\mathrm{A}_{260} / \mathrm{A}_{280}\right.$ ratio) were measured with a NanoDrop ${ }^{\mathrm{TM}} 2000$ spectrophotometer (Thermo Fisher Scientific). RNA integrity and non-DNA contamination were verified on $1 \%$ denatured gels of agarose UltraPure (Invitrogen, Carlsbad, CA, USA) and visualized in a UV transilluminator (Alpha Innotech Corporation, San Leandro, CA, USA). Two $\mu \mathrm{g}$ of RNA were used for cDNA synthesis with High-Capacity RNA-to-cDNA ${ }^{\mathrm{TM}}$ Kit (Applied Biosystems ${ }^{\mathrm{TM}}$ by Thermo Fisher Scientific) according to the manufacturer's protocol. The synthesized cDNA was stored at $-20^{\circ} \mathrm{C}$ until further use $[90,91]$. 


\subsection{Amplification and Cloning of MVA Pathway cDNAs}

In order to obtain the full-length cDNA sequences, PCR amplifications were performed in a thermocycler (Techne, Cambridge, UK) in a total reaction volume of $20 \mu \mathrm{L}: 0.2 \mathrm{mM}$ dNTPs, $2 \mathrm{mM}$ $\mathrm{MgCl}_{2}, 0.5 \mu \mathrm{M}$ of each primer, $0.5 \mu \mathrm{M}$ BSA (AACT, MK, MDPC, GGPPS), DMSO $5 \%$ (with BSA for HMGS, HMGR, GPPS/FPPS), $2 \mu \mathrm{L}$ cDNA and $1.25 \mathrm{U}^{\text {Thermo Scientific }}{ }^{\mathrm{TM}}$ DreamTaq ${ }^{\mathrm{TM}}$ DNA Polymerase (Thermo Fisher Scientific). An initial denaturation step at $94^{\circ} \mathrm{C}$ for $3 \mathrm{~min}$ was followed by 35 cycles of denaturation at $94{ }^{\circ} \mathrm{C}$ for $40 \mathrm{~s}$, annealing for $50 \mathrm{~s}$, and extension at $72{ }^{\circ} \mathrm{C}$, with a final extension of $30 \mathrm{~min}$ for all transcripts. The annealing temperature and the extension time of each cDNA are reported in the supporting information (Table S5).

Primers (Table S5) were designed according to the sequences obtained from the D. rhizophagus transcriptome [92]. The amplicons were purified with GFX PCR DNA and the Gel Band Purification Kit (Illustra GE Healthcare, Chicago, IL, USA), ligated to pGEM ${ }^{\circledR}$-T Easy Vector System I (Promega, Wisconsin, USA), and cloned into chemically competent Escherichia coli DH5 $\alpha$ cells. Plasmid DNA was extracted by the alkaline lysis method [93] and sequenced in a 3730xl DNA Analyzer (Applied Biosystems, CA, USA) at Macrogen Inc., Seoul, Korea.

\subsection{In Silico Characterization of MVA Pathway Genes}

Blast searches for full-length sequences of each gene and putative proteins were made against the NCBI GenBank [94] and UniProt databases for their identification and comparison (\%similarity) with previously reported coleopteran sequences. Nucleotide sequences were translated with the ExPASy Translate tool from the SIB (Swiss Institute of Bioinformatics) [95], and the amino acid sequences were used to predict physicochemical properties, including molecular weight (M.W.) and isoelectric point (pI) using the ProtParam program [96]. Probable subcellular localizations were estimated with the TargetP program (non-plant proteins) [97] and ProtComp v. 9.0 (eukaryotic proteins). Moreover, amino acid sequences were checked for transmembrane helices with TMHMM 2.0 [98]. The ESPript program was used to assign a possible secondary structure to putative D. rhizophagus MVA pathway proteins based on crystal structure data from the Protein Data Bank (PDB) [99].

\subsection{Phylogenetic Analysis}

The complete sequences of the MVA pathway putative enzymes were aligned using Clustal v. 1.2.1 [100] with sequences deposited in the GenBank from other insect groups. ProtTEST v2.4 [101] was used to select the best-fitting protein evolution model for each gene based on the Akaike information criterion. The $\mathrm{LG}+\mathrm{G}+\mathrm{I}+\mathrm{F}$ model was selected for almost all putative proteins, with the exception of HMGR $(\mathrm{JTT}+\mathrm{G}+\mathrm{I}+\mathrm{F})$. Maximum likelihood (ML) phylogenetic analyses were performed in PhyML [102] (http://atgc.lirmm.fr/phyml/) with the determined model for each enzyme. Node support was assessed by 1000 bootstrap replicates. Dipteran sequences were used as the outgroup (accession numbers are given in the corresponding trees).

\section{7. $R T-q P C R$ Assays}

Quantitative real-time PCR (RT-qPCR) was used to obtain the relative expression of MVA pathway genes in the $D$. rhizophagus gut. All experimental procedures related to qPCR were performed according to the Minimum Information for Publication of Quantitative Real-Time PCR Experiments (MIQE) guidelines (Table S6) [103]. For this, solitary females $(n=18)$, solitary males $(n=18)$, as well as pairs $(n=18)$ formed by one male and one female, were fed separately in the dark both for 8 and $24 \mathrm{~h}$. In the case of pairs, each sex was processed individually. Unfed solitary insects (males and females) were included as controls. On the other hand, males and females stimulated with JH III were set independently into 1.5 microcentrifuge tubes in the dark for 8 and $24 \mathrm{~h}$. Insects of both sexes who were treated with $0.5 \mu \mathrm{L}$ of acetone during both exposure times were included as control groups. As these times elapsed, all insects were killed and dissected for total RNA isolation and cDNA synthesis, as 
described above. Three biological replicates were conduced, each one with six guts, for each treatment in the qPCR assays.

Real-time PCR reactions were carried out with a Step One ${ }^{\mathrm{TM}}$ Real-Time PCR System (Applied Biosystems). Primers and a TaqMan ${ }^{\circledR}$ hydrolysis probe for each gene were designed by Applied Biosystems (Table S5); probes were labeled at the 5' end with the reporter dye 6-carboxyfluorescein (FAM) and a non-fluorescent quencher molecule group MGB (Minor Groove Binder) at the $3^{\prime}$ end. Each reaction contained $900 \mathrm{nM}$ of each primer, $250 \mathrm{nM}$ of the TaqMan ${ }^{\circledR}$ probe, TaqMan ${ }^{\circledR}$ Universal Master Mix II and $5 \mu \mathrm{L}$ cDNA in a final volume of $20 \mu$ l. Three technical replicates were performed for each biological replicate. The following standard manufacturer's amplification conditions were used: $50{ }^{\circ} \mathrm{C}$ for $2 \mathrm{~min}, 95^{\circ} \mathrm{C}$ for $10 \mathrm{~min}$, and 40 cycles at $95^{\circ} \mathrm{C}$ for $15 \mathrm{~s}$ and $60^{\circ} \mathrm{C}$ for $60 \mathrm{~s}$. The efficiency and validation $\left(\mathrm{R}^{2}\right)$ of the $\mathrm{qPCR}$ were assessed for each gene with a linear regression analysis of the mean values of the quantification cycles $(\mathrm{Cq})$ from different dilutions of cDNA (efficiency $=\left(\left(10^{-1 / \text { slope }}-1\right)\right.$ $\times 100)$ ). The mean slope value was $-3.22 \pm 0.32$ (s.d.) and the $R^{2}$ values were $>0.96$. All amplicons were visualized in $1 \%$ agarose gel electrophoresis to evaluate the specificity. Relative expression values were calculated according to the $2^{-\Delta \Delta C t}$ method [104], using CYP4G55v1 as the reference gene for normalizing expression levels [90,91,105-107].

\subsection{Statistical Analysis}

A three-way ANOVA was used for the analysis of the following factors: sex (male-female), condition (solitary-paired), and time ( 8 and $24 \mathrm{~h}$ ) in fed insects; and a two-way ANOVA for the analysis of the following factors: sex (male-female) and time ( 8 and $24 \mathrm{~h}$ ) in insects treated with JH III. Tukey's test was performed for pairwise comparisons between factors. The $2^{-\Delta \Delta C t}$ values were used for relative expression plots and statistical analysis with SigmaPlot 12.0 and SigmaStat v. 3.5 software (Systat Software Inc., San Jose, CA, USA).

\subsection{Quantification of Volatile Compounds}

Terpenoid compounds present in the gut of D. rhizophagus males and females were sampled and quantified in: (1) unfed pre-emerged insect; (2) solitary fed males and (3) solitary fed females; (4) fed males paired with females; and (5) fed females paired with males. The unfed pre-emerged insects were immediately processed for analysis by gas chromatography-mass spectrometry (GC-MS). The insects used in the other treatments (2-5) were confined during 18 and $24 \mathrm{~h}$ into uninfested Pinus leiophylla fresh logs. These times were selected because a preliminary analysis demonstrated that in this period, in laboratory conditions, the production of volatiles by insects is better than in shorter times $(<15 \mathrm{~h})$. In addition, to follow up the production of volatiles, these were also recorded and quantified at $43 \mathrm{~h}$. For insects in pairs, females were first introduced alone into the bark during $4 \mathrm{~h}$, and afterwards, a male was introduced with each female and both stayed inside for another 18, 24, and $43 \mathrm{~h}$. Twelve replicates were collected for each treatment and feeding time. All insects were set individually into $0.25 \mathrm{~mL}$ glass inserts (SUPELCO, Sigma-Aldrich Corp., Milwaukee, WI, USA) containing $\sim 0.3 \mathrm{mg}$ of the adsorbent Porapak $\mathrm{Q}$, during $24 \mathrm{~h}$ in dark conditions at room temperature in a stream of purified air, in order to collect the volatiles released by them $[40,108]$. Later, each insect was removed from its vial and dissected to obtain the gut. Volatiles were extracted from the Porapak $Q$ and from the gut tissue with $100 \mu \mathrm{L}$ of hexane spiked with $3.8 \mathrm{ng} / \mu \mathrm{L}$ of cycloheptanone ( 99 purity, Sigma-Aldrich Corp.) as an internal quantitative standard. The tissue was gently macerated against the glass insert wall and reserved for $15 \mathrm{~min}$ for passive extraction at room temperature. Later, the total extract was transferred into a clean glass insert and kept at $-20^{\circ} \mathrm{C}$. Negative control extracts were also collected from glass inserts in which no beetles were introduced.

One microliter of each extract was analyzed by GC-MS (7820A GC System-5975 Series MSD Agilent Technologies, Santa Clara, CA, USA) in splitless mode with a (5\%-Phenyl)-methylpolysiloxane column (Agilent J\&W HP- $5 \mathrm{~ms} 30 \mathrm{~m} \times 0.25 \mathrm{~mm} \times 0.25 \mu \mathrm{m}$ ). The temperature program of the GC oven was $50^{\circ} \mathrm{C}$ for $1 \mathrm{~min}, 2{ }^{\circ} \mathrm{C} / \mathrm{min}$ to $100{ }^{\circ} \mathrm{C}$, then $16^{\circ} \mathrm{C} / \mathrm{min}$ to $200{ }^{\circ} \mathrm{C}$. The quantification of each compound was 
made by internal standardization method and converted to nanograms based on the relative responses obtained from serial dilutions of synthetic standards [fenchyl alcohol (96\% purity, Sigma-Aldrich Corp., Milwaukee, WI, USA), myrtenal (98\% purity, Sigma-Aldrich Corp.), myrtenol (95\% purity, Sigma-Aldrich Corp.), cis-verbenol (95\% purity, Sigma-Aldrich Corp.), trans-verbenol (95\% purity, PheroTech, Delta, BC, Canada), and verbenone (99\% purity, Sigma-Aldrich Corp.). The identification of each compound from the extracts was accomplished by matching the retention times of synthetic standards and mass spectra searches with the NIST Mass Spectral Search Program (version 2.2) for the NIST/NIH/EPA Mass Spectral Library.

\section{Conclusions}

In brief, this study is an effort to determine whether D. rhizophagus engages in the de novo synthesis of pheromones such as frontalin and ipsdienol through the MVA pathway. According to the expression patterns observed in GPPS/FPPS and GGPPS genes, it is unlikely that frontalin or ipsdienol are produced in this species, despite $D$. rhizophagus males presenting higher expression levels than females, as has been reported in other bark beetle species that produce these pheromones $[27,32,48,67]$. These findings were also supported by the GC-MS analysis, which did not record the present of these compounds. The information obtained in this study is relevant because it allow us to understand how two species have divided their ecological niches to co-exist in Mexican Forests, as their chemical ecology diverges. Additionally, further studies are needed to reveal the MVA pathway regulatory mechanisms that govern the production of terpenoid pheromones in different bark beetle species.

Supplementary Materials: Supplementary materials can be found at http://www.mdpi.com/1422-0067/20/16/ 4011/s1. References [109-122] are cited in the supplementary figures.

Author Contributions: Conceptualization, M.F.L., G.O.-M., C.C.-R. and G.Z.; methodology, L.E.S., M.F.L., C.C.-R., G.S.-M. and G.O.-M.; formal analysis, L.E.S., M.F.L., G.O.-M., C.C.-R. and G.Z.; investigation, L.E.S., M.F.L., G.O.-M., G.S.-M., C.C.-R. and G.Z.; resources, M.F.L., G.S.-M. and G.Z.; writing-original draft preparation, L.E.S., M.F.L., G.O.-M., and G.Z.; writing—review and editing, L.E.S., M.F.L., C.C.-R., G.S.-M., G.O.-M., and G.Z.; supervision, M.F.L., and G.Z.; project administration, G.Z.; funding acquisition, G.Z.

Funding: This research was funded by the Consejo Nacional de Ciencia y Tecnología, CONACyT-CB 2012/181337.

Acknowledgments: We thank José L. Aguilar Vitela (SRMNA, Durango State Government) for his assistance in the collection of biological material and for logistic support, and Martha O. Macías Navarro (INIFAP-C.E. Pabellón) for her assistance in the operation of the GC-MS equipment. This work was part of LES's Ph.D. dissertation. LES (262853) was CONACYT and BEIFI-IPN ("Beca de Estímulo Institucional de Formación de Investigadores") fellow.

Conflicts of Interest: The authors declare no conflict of interest.

\section{Abbreviations}

MVA Mevalonate

RT-qPCR Quantitative real-time Polymerase Chain Reaction

GC-MS Gas Chromatography Mass Spectrometry

\section{References}

1. Billings, R.F.; Clarke, S.R.; Espino-Mendoza, V.; Cordón-Cabrera, P.; Meléndez-Figueroa, B.; Ramón-Campos, J.; Baeza, G. Bark beetle outbreaks and fire: A devastating combination for Central America's pine forest. Unasylva 2004, 217, 15-21.

2. Raffa, K.F.; Aukema, B.H.; Bentz, B.J.; Carroll, A.L.; Hicke, J.; Turner, M.G.; Romme, W.H. Cross-scale drivers of natural disturbances prone to anthropogenic amplification: The dynamics of bark beetle eruptions. BioScience 2008, 58, 501-517. [CrossRef]

3. Borden, J.H. Aggregation pheromones. In Bark Beetles in North American Conifers: A System for the Study of Evolutionary Biology; Mitton, J.B., Sturgeon, K.M., Eds.; University of Texas Press: Austin, TX, USA, 1982; pp. 74-139.

4. Tittiger, C.; Blomquist, G.J. Pheromone biosynthesis in bark beetles. Curr. Opin. Insect Sci. 2017, $24,68-74$. [CrossRef] [PubMed] 
5. Seybold, S.J.; Huber, D.P.W.; Lee, J.C.; Graves, A.D.; Bohlmann, J. Pine monoterpenes and pine bark beetles: A marriage of convenience for defense and chemical communication. Phytochem. Rev. 2006, 5, 143-178. [CrossRef]

6. Wyatt, T.D. Pheromones and Animal Behavior: Chemical Signals and Signatures, 2nd ed.; University Press: Cambridge, UK, 2014; pp. 65-103.

7. Hunt, D.W.A.; Borden, J.H. Conversion of verbenols to verbenone by yeasts isolated from Dendroctonus ponderosae (Coleoptera: Scolytidae). J. Chem. Ecol. 1990, 16, 1385-1397. [CrossRef] [PubMed]

8. Hunt, D.W.A.; Borden, J.H.; Lindgren, B.S.; Gries, G. The role of autoxidation of $\alpha$-pinene in the production of pheromones of Dendroctonus ponderosae (Coleoptera: Scolytidae). Can. J. For. Res. 1989, 19, 1275-1282. [CrossRef]

9. Chiu, C.C.; Keeling, C.I.; Bohlmann, J. Monoterpenyl esters in juvenile mountain pine beetle and sex-specific release of the aggregation pheromone trans-verbenol. Proc. Natl. Acad. Sci. USA 2018, 115, 3652-3657. [CrossRef] [PubMed]

10. Chiu, C.C.; Keeling, C.I.; Bohlmann, J. The cytochrome P450 CYP6DE1 catalyzes the conversion of $\alpha$-pinene into the mountain pine beetle aggregation pheromone trans-verbenol. Sci. Rep. 2019, 9, 1477. [CrossRef]

11. Sandstrom, P.; Welch, W.H.; Blomquist, G.J.; Tittiger, C. Functional expression of a bark beetle cytochrome P450 that hydroxylates myrcene to ipsdienol. Insect Biochem. Mol. Biol. 2006, 36, 835-845. [CrossRef]

12. Sandstrom, P.; Ginzel, M.D.; Bearfield, J.C.; Welch, W.H.; Blomquist, G.J.; Tittiger, C. Myrcene hydroxylases do not determine enantiomeric composition of pheromonal ipsdienol in Ips spp. J. Chem. Ecol. 2008, 34, 1584-1592. [CrossRef]

13. Seybold, S.J.; Quilici, D.R.; Tillman, J.A.; Vanderwel, D.; Wood, D.L.; Blomquist, G.J. De novo biosynthesis of the aggregation pheromone components ipsenol and ipsdienol by the pine bark beetles Ips paraconfusus Lanier and Ips pini (Say)(Coleoptera: Scolytidae). Proc. Natl. Acad. Sci. USA 1995, 92, 8393-8397. [CrossRef] [PubMed]

14. Song, M.; Kim, A.C.; Gorzalski, A.J.; MacLean, M.; Young, S.; Ginzel, M.D.; Blomquist, G.J.; Tittiger, C. Functional characterization of myrcene hydroxylases from two geographically distinct Ips pini populations. Insect Biochem. Mol. Biol. 2013, 43, 336-343. [CrossRef] [PubMed]

15. Song, M.; Gorzalski, A.; Nguyen, T.T.; Liu, X.; Jeffrey, C.; Blomquist, G.J.; Tittiger, C. exo-Brevicomin biosynthesis in the fat body of the mountain pine beetle, Dendroctonus ponderosae. J. Chem. Ecol. 2014, 40, 181-189. [CrossRef] [PubMed]

16. Byers, J.A. Chemical ecology of bark beetles. Experientia 1989, 45, 271-283. [CrossRef]

17. Erbilgin, N.; Mori, S.R.; Sun, J.H.; Stein, J.D.; Owen, D.R.; Merrill, L.D.; Campos Bolaños, R.; Raffa, K.F.; Méndez Montiel, T.; Wood, D.L.; et al. Response to host volatiles by native and introduced populations of Dendroctonus valens (Coleptera: Curculionidae, Scolytinae) in North America and China. J. Chem. Ecol. 2007, 33, 131-146. [CrossRef] [PubMed]

18. Kirkendall, L.R. The evolution of mating systems in bark and ambrosia beetles (Coleoptera: Scolytidae and Platypodidae). Zool. J. Linn. Soc. 1983, 77, 293-352. [CrossRef]

19. Miller, D.R.; Borden, J.H. Dose-dependent and species-specific responses of pine bark beetles (Coleoptera: Scolytidae) to monoterpenes in association with pheromones. Can. Entomol. 2000, 132, 183-195. [CrossRef]

20. Lombard, J.; Moreira, D. Origins and early evolution of the mevalonate pathway of isoprenoid biosynthesis in the three domains of life. Mol. Biol. Evol. 2010, 28, 87-99. [CrossRef]

21. Matsumi, R.; Atomi, H.; Driessen, A.J.; van der Oost, J. Isoprenoid biosynthesis in Archaea-biochemical and evolutionary implications. Res. Microbiol. 2011, 162, 39-52. [CrossRef]

22. Yeganeh, B.; Wiechec, E.; Ande, S.R.; Sharma, P.; Moghadam, A.R.; Post, M.; Freed, D.H.; Hashemi, M.; Shojaei, S.; Zeki, A.A.; et al. Targeting the mevalonate cascade as a new therapeutic approach in heart disease, cancer and pulmonary disease. Pharmacol. Ther. 2014, 143, 87-110. [CrossRef]

23. Blomquist, G.J.; Figueroa-Teran, R.; Aw, M.; Song, M.; Gorzalski, A.; Abbott, N.L.; Chang, E.; Tittiger, C. Pheromone production in bark beetles. Insect Biochem. Mol. Biol. 2010, 40, 699-712. [CrossRef]

24. Hall, G.M.; Tittiger, C.; Blomquist, G.J.; Andrews, G.L.; Mastick, G.S.; Barkawi, L.S.; Bengoa, C.; Seybold, S.J. Male Jeffrey pine beetle, Dendroctonus jeffreyi, synthesizes the pheromone component frontalin in anterior midgut tissue. Insect Biochem. Mol. Biol. 2002, 32, 1525-1532. [CrossRef] 
25. Hall, G.M.; Tittiger, C.; Andrews, G.L.; Mastick, G.S.; Kuenzli, M.; Luo, X.; Seybold, S.J.; Blomquist, G.J. Midgut tissue of male pine engraver, Ips pini, synthesizes monoterpenoid pheromone component ipsdienol de novo. Naturwissenschaften 2002, 89, 79-83. [CrossRef]

26. Nardi, J.B.; Young, A.G.; Ujhelyi, E.; Tittiger, C.; Lehane, M.J.; Blomquist, G.J. Specialization of midgut cells for synthesis of male isoprenoid pheromone components in two scolytid beetles, Dendroctonus jeffreyi and Ips pini. Tissue Cell 2002, 34, 221-231. [CrossRef]

27. Tittiger, C.; O’Keeffe, C.; Bengoa, C.S.; Barkawi, L.S.; Seybold, S.J.; Blomquist, G.J. Isolation and endocrine regulation of an HMG-CoA synthase cDNA from the male Jeffrey pine beetle, Dendroctonus jeffreyi (Coleoptera: Scolytidae). Insect Biochem. Mol. Biol. 2000, 30, 1203-1211. [CrossRef]

28. Tittiger, C.; Barkawi, L.S.; Bengoa, C.S.; Blomquist, G.J.; Seybold, S.J. Structure and juvenile hormone-mediated regulation of the HMG-CoA reductase gene from the Jeffrey pine beetle, Dendroctonus jeffreyi. Mol. Cell Endocrinol. 2003, 199, 11-21. [CrossRef]

29. Tillman, J.A.; Holbrook, G.L.; Dallara, P.L.; Schal, C.; Wood, D.L.; Blomquist, G.J. Endocrine regulation of de novo aggregation pheromone biosynthesis in the pine engraver, Ips pini (Say) (Coleoptera: Scolytidae). Insect Biochem. Mol. Biol. 1998, 28, 705-715. [CrossRef]

30. Bellés, X.; Martín, D.; Piulachs, M.D. The mevalonate pathway and the synthesis of juvenile hormone in insects. Annu. Rev. Entomol. 2005, 50, 181-199. [CrossRef]

31. Miziorko, H.M. Enzymes of the mevalonate pathway of isoprenoid biosynthesis. Arch. Biochem. Biophys. 2011, 505, 131-143. [CrossRef]

32. Keeling, C.I.; Blomquist, G.J.; Tittiger, C. Coordinated gene expression for pheromone biosynthesis in the pine engraver beetle, Ips pini (Coleoptera: Scolytidae). Naturwissenschaften 2004, 91, 324-328. [CrossRef]

33. Frick, S.; Nagel, R.; Schmidt, A.; Bodemann, R.R.; Rahfeld, P.; Pauls, G.; Brandt, W.; Gershenzon, J.; Boland, W.; Burse, A. Metal ions control product specificity of isoprenyl diphosphate synthases in the insect terpenoid pathway. Proc. Natl. Acad. Sci. USA 2013, 110, 4194-4199. [CrossRef]

34. Sen, S.E.; Brown, D.C.; Sperry, A.E.; Hitchcock, J.R. Prenyltransferase of larval and adult M. sexta corpora allata. Insect Biochem. Mol. Biol. 2007, 37, 29-40. [CrossRef]

35. Vandermoten, S.; Charloteaux, B.; Santini, S.; Sen, S.E.; Béliveau, C.; Vandenbol, M.; Francis, F.; Brasseur, R.; Cusson, M.; Haubruge, E. Characterization of a novel aphid prenyltransferase displaying dual geranyl/farnesyl diphosphate synthase activity. FEBS Lett. 2008, 582, 1928-1934. [CrossRef]

36. Keeling, C.I.; Chiu, C.C.; Aw, T.; Li, M.; Henderson, H.; Tittiger, C.; Weng, H.B.; Blomquist, G.J.; Bohlmann, J. Frontalin pheromone biosynthesis in the mountain pine beetle, Dendroctonus ponderosae, and the role of isoprenyl diphosphate synthases. Proc. Natl. Acad. Sci. USA 2013, 110, 18838-18843. [CrossRef]

37. Mendoza, M.G.; Salinas-Moreno, Y.; Olivo-Martínez, A.; Zúñiga, G. Factors influencing the geographical distribution of Dendroctonus rhizophagus (Coleoptera: Curculionidae: Scolytinae) in the Sierra Madre Occidental México. Environ. Entomol. 2011, 40, 549-559. [CrossRef]

38. Sánchez-Martínez, G.; Wagner, M.R. Host preference and attack pattern of Dendroctonus rhizophagus (Coleoptera: Curculionidae: Scolytinae): A bark beetle specialist on pine regeneration. Environ. Entomol. 2009, 38, 1197-1204. [CrossRef]

39. Cibrián-Tovar, D.; Méndez-Montiel, J.T.; Campos-Bolaños, R.; Yates III, H.O.; Flores-Lara, J. Insectos Forestales de México/Forests Insects of México COFAN/NAFC; Universidad Autónoma Chapingo: Texcoco, Mexico, 1995.

40. Cano-Ramírez, C.; Armendáriz-Toledano, F.; Macías-Sámano, J.E.; Sullivan, B.T.; Zúñiga, G. Electrophysiological and behavioral responses of the bark beetle Dendroctonus rhizophagus to volatiles from host pines and conspecifics. J. Chem. Ecol. 2012, 38, 512-524. [CrossRef]

41. Niño-Domínguez, A.; Sullivan, B.T.; López-Urbina, J.H.; Macías-Sámano, J.E. Pheromone-mediated mate location and discrimination by two syntopic sibling species of Dendroctonus bark beetles in Chiapas, Mexico. J. Chem. Ecol. 2015, 41, 746-756. [CrossRef]

42. Symonds, M.R.E.; Gitau-Clarke, C.W. The evolution of aggregation pheromone diversity in bark beetles. In Advances in Insect Physiology; Tittiger, C., Blomquist, G.J., Eds.; Academic Press: New York, NY, USA, 2016; Volume 50, pp. 195-234.

43. Kinzer, G.W.; Fentiman, A.F., Jr.; Page, T.F., Jr.; Foltz, R.L.; Vité, J.P.; Pitman, G.B. Bark beetle attractants: Identification, synthesis and field bioassay of a new compound isolated from Dendroctonus. Nature 1969, 221, 477. [CrossRef] 
44. Pureswaran, D.S.; Gries, R.; Borden, J.H.; Pierce, H.D., Jr. Dynamics of pheromone production and communication in the mountain pine beetle, Dendroctonus ponderosae Hopkins, and the pine engraver, Ips pini (Say) (Coleoptera: Scolytidae). Chemoecology 2000, 10, 153-168. [CrossRef]

45. Rudinsky, J.A.; Morgan, M.E.; Libbey, L.M.; Putnam, T.B. Antiaggregative-rivalry pheromone of the mountain pine beetle, and a new arrestant of the southern pine beetle. Environ. Entomol. 1974, 3, 90-98. [CrossRef]

46. Liu, Z.; Xu, B.; Miao, Z.; Sun, J. The pheromone frontalin and its dual function in the invasive bark beetle Dendroctonus valens. Chem. Senses. 2013, 38, 485-495. [CrossRef]

47. Bearfield, J.C.; Henry, A.G.; Tittiger, C.; Blomquist, G.J.; Ginzel, M.D. Two regulatory mechanisms of monoterpenoid pheromone production in Ips spp. of bark beetles. J. Chem. Ecol. 2009, 35, 689-697. [CrossRef]

48. Yu, J.; Dai, L.; Zhang, R.; Li, Z.; Pham, T.; Chen, H. Isolation and expression of HMG-CoA synthase and HMG-CoA reductase genes in different development stages, tissues and treatments of the Chinese white pine beetle, Dendroctonus armandi (Curculionidae: Scolytinae). Comp. Biochem. Physiol. B Biochem. Mol. Biol. 2015, 187, 62-70. [CrossRef]

49. Barkawi, L.S.; Francke, W.; Blomquist, G.J.; Seybold, S.J. Frontalin: De novo biosynthesis of an aggregation pheromone component by Dendroctonus spp. bark beetles (Coleoptera: Scolytidae). Insect Biochem. Mol. Biol. 2003, 33, 773-788. [CrossRef]

50. Fukao, T.; Song, X.Q.; Mitchell, G.A.; Yamaguchi, S.; Sukegawa, K.; Orii, T.; Kondo, N. Enzymes of ketone body utilization in human tissues: Protein and messenger RNA levels of succinyl-coenzyme A (CoA): 3-ketoacid CoA transferase and mitochondrial and cytosolic acetoacetyl-CoA thiolases. Pediatr. Res. 1997, 42, 498-502. [CrossRef]

51. Fujii, T.; Ito, K.; Katsuma, S.; Nakano, R.; Shimada, T.; Ishikawa, Y. Molecular and functional characterization of an acetyl-CoA acetyltransferase from the adzuki bean borer moth Ostrinia scapulalis (Lepidoptera: Crambidae). Insect Biochem. Mol. Biol. 2010, 40, 74-78. [CrossRef]

52. Mascaró, C.; Buesa, C.; Ortiz, J.A.; Haro, D.; Hegardt, F.G. Molecular cloning and tissue expression of human mitochondrial 3-hydroxy-3-methylglutaryl-CoA synthase. Arch. Biochem. Biophys. 1995, 317, 385-390. [CrossRef]

53. Ayté, J.; Gil-Gómez, G.; Haro, D.; Marrero, P.F.; Hegardt, F.G. Rat mitochondrial and cytosolic 3-hydroxy-3-methylglutaryl-CoA synthases are encoded by two different genes. Proc. Natl. Acad. Sci. USA 1990, 87, 3874-3878. [CrossRef]

54. Martínez-González, J.; Buesa, C.; Piulachs, M.D.; Belles, X.; Hegardt, F.G. 3-Hydroxy-3-methylglutarylcoenzyme-A synthase from Blattella germanica: Cloning, expression, developmental pattern and tissue expression. Eur. J. Biochem. 1993, 217, 691-699. [CrossRef]

55. Couillaud, F.; Feyereisen, R. Assay of HMG-CoA synthase in Diploptera punctata corpora allata. Insect Biochem. 1991, 21, 131-135. [CrossRef]

56. Jingami, H.; Brown, M.S.; Goldstein, J.L.; Anderson, R.G.W.; Luskey, K.L. Partial deletion of membrane-bound domain of 3-hydroxy-3-methylglutaryl coenzyme A reductase eliminates sterol-enhanced degradation and prevents formation of crystalloid endoplasmic reticulum. J. Cell Biol. 1987, 104, 1693-1704. [CrossRef]

57. Liscum, L.; Finer-Moore, J.; Stroud, R.M.; Luskey, K.L.; Brown, M.S.; Goldstein, J.L. Domain structure of 3-hydroxy-3-methylglutaryl coenzyme A reductase, a glycoprotein of the endoplasmic reticulum. J. Biol. Chem. 1985, 260, 522-530.

58. Feyereisen, R.; Farnsworth, D.E. Characterization and regulation of HMG-CoA reductase during a cycle of juvenile hormone synthesis. Mol. Cell Endocrinol. 1987, 53, 227-238. [CrossRef]

59. Barnes, F.J.; Goodfellow, R.D. Mevalonate kinase: Localization and variation in activity during the development of Sarcophaga bullata. J. Insect Physiol. 1971, 17, 1415-1427. [CrossRef]

60. Hogenboom, S.; Tuyp, J.J.M.; Espeel, M.; Koster, J.; Wanders, R.J.A.; Waterham, H.R. Phosphomevalonate kinase is a cytosolic protein in humans. J. Lipid Res. 2004, 45, 697-705. [CrossRef]

61. Biardi, L.; Krisans, S.K. Compartmentalization of Cholesterol Biosynthesis Conversion of mevalonate to farnesyl diphosphate occurs in the peroxisomes. J. Biol. Chem. 1996, 271, 1784-1788. [CrossRef]

62. Olivier, L.M.; Chambliss, K.L.; Gibson, K.M.; Krisans, S.K. Characterization of phosphomevalonate kinase: Chromosomal localization, regulation, and subcellular targeting. J. Lipid Res. 1999, 40, 672-679.

63. Ericsson, J.; Runquist, M.; Thelin, A.; Andersson, M.; Chojnacki, T.; Dallner, G. Distribution of prenyltransferases in rat tissues. Evidence for a cytosolic all-trans-geranylgeranyl diphosphate synthase. J. Biol. Chem. 1993, 268, 832-838. 
64. Krisans, S.K.; Ericsson, J.; Edwards, P.A.; Keller, G.A. Farnesyl-diphosphate synthase is localized in peroxisomes. J. Biol. Chem. 1994, 269, 14165-14169.

65. Martín, D.; Piulachs, M.D.; Cunillera, N.; Ferrer, A.; Bellés, X. Mitochondrial targeting of farnesyl diphosphate synthase is a widespread phenomenon in eukaryotes. Biochim. Biophys. Acta. 2007, 1773, 419-426. [CrossRef]

66. Paton, V.G.; Shackelford, J.E.; Krisans, S.K. Cloning and subcellular localization of hamster and rat isopentenyl diphosphate dimethylallyl diphosphate isomerase. A PTS1 motif targets the enzyme to peroxisomes. J. Biol. Chem. 1997, 272, 18945-18950. [CrossRef]

67. Bearfield, J.C.; Keeling, C.I.; Young, S.; Blomquist, G.J.; Tittiger, C. Isolation, endocrine regulation and mRNA distribution of the 3-hydroxy-3-methylglutaryl coenzyme A synthase (HMG-S) gene from the pine engraver, Ips pini (Coleoptera: Scolytidae). Insect Mol. Biol. 2006, 15, 187-195. [CrossRef]

68. Tittiger, C.; Blomquist, G.J.; Ivarsson, P.; Borgeson, C.E.; Seybold, S.J. Juvenile hormone regulation of HMG-R gene expression in the bark beetle Ips paraconfusus (Coleoptera: Scolytidae): Implications for male aggregation pheromone biosynthesis. Cell Mol. Life Sci. 1999, 55, 121-127. [CrossRef]

69. Goldstein, J.L.; Brown, M.S. Regulation of the mevalonate pathway. Nature. 1990, 343, 425-430. [CrossRef]

70. Keeling, C.I.; Bearfield, J.C.; Young, S.; Blomquist, G.J.; Tittiger, C. Effects of juvenile hormone on gene expression in the pheromone-producing midgut of the pine engraver beetle, Ips pini. Insect Mol. Biol. 2006, 15, 207-216. [CrossRef]

71. Aw, T.; Schlauch, K.; Keeling, C.I.; Young, S.; Bearfield, J.C.; Blomquist, G.J.; Tittiger, C. Functional genomics of mountain pine beetle (Dendroctonus ponderosae) midguts and fat bodies. BMC Genom. 2010, 11, 215. [CrossRef]

72. Burg, J.S.; Espenshade, P.J. Regulation of HMG-CoA reductase in mammals and yeast. Prog. Lipid Res. 2011, 50, 403-410. [CrossRef]

73. Burg, J.S.; Powell, D.W.; Chai, R.; Hughes, A.L.; Link, A.J.; Espenshade, P.J. Insig regulates HMG-CoA reductase by controlling enzyme phosphorylation in fission yeast. Cell Metab. 2008, 8, 522-531. [CrossRef]

74. Li, H.; Wang, H.; Hackett, M.; Schooley, D.A. The structure of dolichols isolated from Manduca sexta larvae. Insect Biochem. Mol. Biol. 1995, 25, 1019-1026. [CrossRef]

75. Lindorfer, M.A.; Sherman, N.E.; Woodfork, K.A.; Fletcher, J.E.; Hunt, D.F.; Garrison, J.C. G protein $\gamma$ subunits with altered prenylation sequences are properly modified when expressed in Sf9 cells. J. Biol. Chem. 1996, 271, 18582-18587. [CrossRef]

76. Silberkang, M.; Havel, C.M.; Friend, D.S.; McCarthy, B.J.; Watson, J.A. Isoprene synthesis in isolated embryonic Drosophila cells. I. Sterol-deficient eukaryotic cells. J. Biol. Chem. 1983, 258, 8503-8511.

77. Gilg, A.B.; Bearfield, J.C.; Tittiger, C.; Welch, W.H.; Blomquist, G.J. Isolation and functional expression of an animal geranyl diphosphate synthase and its role in bark beetle pheromone biosynthesis. Proc. Natl. Acad. Sci. USA 2005, 102, 9760-9765. [CrossRef]

78. Gilg, A.B.; Tittiger, C.; Blomquist, G.J. Unique animal prenyltransferase with monoterpene synthase activity. Naturwissenschaften 2009, 96, 731-735. [CrossRef]

79. Zhao, M.; Dai, L.; Fu, D.; Gao, J.; Chen, H. Electrophysiological and behavioral responses of Dendroctonus armandi (Coleoptera: Curculionidae: Scolytinae) to two candidate pheromone components: Frontalin and exo-brevicomin. Chemoecology 2017, 27, 91-99. [CrossRef]

80. Grégoire, J.C. The greater European spruce beetle. In Dynamics of Forest Insect Populations, 1st ed.; Springer: Boston, MA, USA, 1988; pp. 455-478.

81. Furniss, M.M. Biology of Dendroctonus punctatus (Coleoptera: Scolytidae). Ann. Entomol. Soc. Am. 1995, 88, 173-182. [CrossRef]

82. Furniss, R.L.; Carolin, V.M. Western Forest Insects; No. 1339; USDA Forest Service, Miscellaneous Publication: Washington, DC, USA, 1977.

83. Wood, S.L. Tribe Tomicini. Genus Dendroctonus Erichson. In The Bark and Ambrosia Beetles of North and Central America (Coleoptera: Scolytidae), a Taxonomic Monograph; Brigham Young University: Provo, UT, USA, 1982; pp. 150-203.

84. Zúñiga, G. Personal Communication; Instituto Politécnico Nacional: Mexico City, Mexico, 2019.

85. Zúñiga, G.; Correa, G.M.; Cisneros, R.; Moreno, Y.S. Zonas de sobreposición en las áreas de distribución geográfica de las especies mexicanas de Dendroctonus Erichson (Coleoptera: Scolytidae) y sus implicaciones ecológico-evolutivas. Acta Zool. Mex. 1999, 77, 1-22. [CrossRef] 
86. Byers, J.A. Bark beetle conversion of a plant compound to a sex-specific inhibitor of pheromone attraction. Science 1983, 220, 624-626. [CrossRef]

87. Renwick, J.A.; Hughes, P.R.; Krull, I.S. Selective production of cis-and trans-verbenol from (-)-and (+)-alpha by a bark beetle. Science 1976, 191, 199-201. [CrossRef]

88. Francke, W.; Vité, J.P. Oxygenated terpenes in pheromone systems of bark beetles. Z. Angew. Entomol. 1983, 96, 146-156. [CrossRef]

89. Armendáriz-Toledano, F.; Zúñiga, G. Illustrated Key to Species of Genus Dendroctonus (Coleoptera: Curculionidae) Occurring in Mexico and Central America. J. Insect Sci. 2017, 17, 1-15. [CrossRef]

90. Cano-Ramírez, C.; López, M.F.; Cesar-Ayala, A.K.; Pineda-Martínez, V.; Sullivan, B.T.; Zúñiga, G. Isolation and expression of cytochrome P450 genes in the antennae and gut of pine beetle Dendroctonus rhizophagus (Curculionidae: Scolytinae) following exposure to host monoterpenes. Gene 2013, 520, 47-63. [CrossRef]

91. López, M.F.; Cano-Ramírez, C.; Cesar-Ayala, A.K.; Ruiz, E.A.; Zúñiga, G. Diversity and expression of P450 genes from Dendroctonus valens LeConte (Curculionidae: Scolytinae) in response to different kairomones. Insect Biochem. Mol. Biol. 2013, 43, 417-432. [CrossRef]

92. Torres-Banda, V.; López, M.F.; Obregón-Molina, G.; Zuñiga, G. Identification and Comparison of Genes Associated with Detoxification Process between Two Sibling Bark Beetle Species by Intestine-Specific Transcriptome Profile Analysis. Unpublished work. 2019.

93. Sambrook, J.; Fritsch, E.F.; Maniatis, T. Molecular Cloning: A Laboratory Manual; Cold Spring Harbor Laboratory Press: New York, NY, USA, 1989.

94. Altschul, S.F.; Gish, W.; Miller, W.; Myers, E.W.; Lipman, D.J. Basic local alignment search tool. J. Mol. Biol. 1990, 215, 403-410. [CrossRef]

95. Artimo, P.; Jonnalagedda, M.; Arnold, K.; Baratin, D.; Csardi, G.; de Castro, E.; Duvaud, S.; Flegel, V.; Fortier, A.; Gasteiger, E.; et al. ExPASy: SIB bioinformatics resource portal. Nucleic Acids Res. 2012, 40, W597-W603. [CrossRef]

96. Gasteiger, E.; Hoogland, C.; Gattiker, A.; Duvaud, S.; Wilkins, M.R.; Appel, R.D.; Bairoch, A. Protein Identification and Analysis Tools on the ExPASy Server. In The Proteomics Protocols Handbook; Walker, J.M., Ed.; Humana Press: Totowa, NJ, USA, 2005; pp. 571-607.

97. Emanuelsson, O.; Nielsen, H.; Brunak, S.; von Heijne, G. Predicting subcellular localization of proteins based on their N-terminal amino acid sequence. J. Mol. Biol. 2000, 300, 1005-1016. [CrossRef]

98. Sonnhammer, E.L.; Von Heijne, G.; Krogh, A. A hidden Markov model for predicting transmembrane helices in protein sequences. In Sixth International Conference on Intelligent Systems for Molecular Biology; Glasgow, J., Littlejohn, T., Major, F., Lathrop, R., Sankoff, D., Sensen, C., Eds.; AAAI Press: Menlo Park, CA, USA, 1998.

99. Gouet, P.; Robert, X.; Courcelle, E. ESPript/ENDscript: Extracting and rendering sequence and 3D information from atomic structures of proteins. Nucleic Acids Res. 2003, 31, 3320-3323. [CrossRef]

100. Sievers, F.; Wilm, A.; Dineen, D.; Gibson, T.J.; Karplus, K.; Li, W.; Lopez, R.; McWilliam, H.; Remmert, M.; Söding, J.; et al. Fast, scalable generation of high-quality protein multiple sequence alignments using Clustal Omega. Mol. Syst. Biol. 2011, 7, 539. [CrossRef]

101. Abascal, F.; Zardoya, R.; Posada, D. ProtTest: Selection of best-fit models of protein evolution. Bioinformatics 2005, 21, 2104-2105. [CrossRef]

102. Lefort, V.; Longueville, J.E.; Gascuel, O. SMS: Smart model selection in PhyML. Mol. Biol. Evol. 2017, 34, 2422-2424. [CrossRef]

103. Bustin, S.A.; Benes, V.; Garson, J.A.; Hellemans, J.; Huggett, J.; Kubista, M.; Mueller, R.; Nolan, T.; Pfaffl, M.W.; Shipley, G.L.; et al. The MIQE guidelines: Minimum information for publication of quantitative real-time PCR experiments. Clin. Chem. 2009, 55, 611-622. [CrossRef]

104. Livak, K.J.; Schmittgen, T.D. Analysis of relative gene expression data using real-time quantitative PCR and the $2^{-\Delta \Delta C T}$ method. Methods 2001, 25, 402-408. [CrossRef]

105. Dai, L.; Ma, M.; Wang, C.; Shi, Q.; Zhang, R.; Chen, H. Cytochrome P450s from the Chinese white pine beetle, Dendroctonus armandi (Curculionidae: Scolytinae): Expression profiles of different stages and responses to host allelochemicals. Insect Biochem. Mol. Biol. 2015, 65, 35-46. [CrossRef]

106. Dai, L.; Ma, M.; Gao, G.; Chen, H. Dendroctonus armandi (Curculionidae: Scolytinae) cytochrome P450s display tissue specificity and responses to host terpenoids. Comp. Biochem. Physiol. B Biochem. Mol. Biol. 2016, 201, 1-11. [CrossRef] 
107. Obregón-Molina, G.; Cesar-Ayala, A.K.; López, M.F.; Cano-Ramírez, C.; Zúñiga, G. Comparison of orthologous cytochrome $\mathrm{P} 450$ genes relative expression patterns in the bark beetles Dendroctonus rhizophagus and Dendroctonus valens (Curculionidae: Scolytinae) during host colonization. Insect Mol. Biol. 2015, 24, 649-661. [CrossRef]

108. Sullivan, B.T. Electrophysiological and behavioral responses of Dendroctonus frontalis (Coleoptera: Curculionidae) to volatiles isolated from conspecifics. J. Econ. Entomol. 2005, 98, 2067-2078. [CrossRef]

109. Sirinupong, N.; Suwanmanee, P.; Doolittle, R.F.; Suvachitanont, W. Molecular cloning of a new cDNA and expression of 3-hydroxy-3-methylglutaryl-CoA synthase gene from Hevea brasiliensis. Planta 2005, 221, 502-512. [CrossRef]

110. Andrade-Pavón, D.; Cuevas-Hernández, R.I.; Trujillo-Ferrara, J.G.; Hernández-Rodríguez, C.; Ibarra, J.A.; Villa-Tanaca, L. Recombinant 3-hydroxy 3-methyl glutaryl-CoA reductase from Candida glabrata (Rec-CgHMGR) obtained by heterologous expression, as a novel therapeutic target model for testing synthetic drugs. Appl. Biochem. Biotechnol. 2017, 182, 1478-1490. [CrossRef]

111. Potter, D.; Miziorko, H.M. Identification of catalytic residues in human mevalonate kinase. J. Biol. Chem. 1997, 272, 25449-25454. [CrossRef]

112. Schafer, B.L.; Bishop, R.W.; Kratunis, V.J.; Kalinowski, S.S.; Mosley, S.T.; Gibson, K.M.; Tanaka, R.D. Molecular cloning of human mevalonate kinase and identification of a missense mutation in the genetic disease mevalonic aciduria. J. Biol. Chem. 1992, 267, 13229-13238.

113. Yang, D.; Shipman, L.W.; Roessner, C.A.; Scott, A.I.; Sacchettini, J.C. Structure of the Methanococcus jannaschii mevalonate kinase, a member of the GHMP kinase superfamily. J. Biol. Chem. 2002, 277, 9462-9467. [CrossRef]

114. Herdendorf, T.J.; Miziorko, H.M. Phosphomevalonate kinase: Functional investigation of the recombinant human enzyme. Biochemistry 2006, 45, 3235-3242. [CrossRef]

115. Smit, A.; Mushegian, A. Biosynthesis of isoprenoids via mevalonate in Archaea: The lost pathway. Genome Res. 2000, 10, 1468-1484. [CrossRef]

116. Byres, E.; Alphey, M.S.; Smith, T.K.; Hunter, W.N. Crystal structures of Trypanosoma brucei and Staphylococcus aureus mevalonate diphosphate decarboxylase inform on the determinants of specificity and reactivity. J. Mol. Biol. 2007, 371, 540-553. [CrossRef]

117. Krepkiy, D.; Miziorko, H.M. Identification of active site residues in mevalonate diphosphate decarboxylase: Implications for a family of phosphotransferases. Protein Sci. 2004, 13, 1875-1881. [CrossRef]

118. Chen, R.; Harada, Y.; Bamba, T.; Nakazawa, Y.; Gyokusen, K. Overexpression of an isopentenyl diphosphate isomerase gene to enhance trans-polyisoprene production in Eucommia ulmoides Oliver. BMC Biotechnol. 2012, 12, 78. [CrossRef]

119. Diaz, M.E.; Mayoral, J.G.; Priestap, H.; Nouzova, M.; Rivera-Perez, C.; Noriega, F.G. Characterization of an isopentenyl diphosphate isomerase involved in the juvenile hormone pathway in Aedes aegypti. Insect Biochem. Mol. Biol. 2012, 42, 751-757. [CrossRef]

120. Chen, A.; Kroon, P.A.; Poulter, C.D. Isoprenyl diphosphate synthases: Protein sequence comparisons, a phylogenetic tree, and predictions of secondary structure. Protein Sci. 1994, 3, 600-607. [CrossRef]

121. Thabet, I.; Guirimand, G.; Guihur, A.; Lanoue, A.; Courdavault, V.; Papon, N.; Bouzid, S.; Giglioli-Guivarc'h, N.; Simkin, A.J.; Clastre, M. Characterization and subcellular localization of geranylgeranyl diphosphate synthase from Catharanthus roseus. Mol. Biol. Rep. 2012, 39, 3235-3243. [CrossRef]

122. Zhu, X.; Suzuki, K.; Saito, T.; Okada, K.; Tanaka, K.; Nakagawa, T. Geranylgeranyl pyrophosphate synthase encoded by the newly isolated gene GGPS6 from Arabidopsis thaliana is localized in mitochondria. Plant Mol. Biol. 1997, 35, 331-341. [CrossRef]

(C) 2019 by the authors. Licensee MDPI, Basel, Switzerland. This article is an open access article distributed under the terms and conditions of the Creative Commons Attribution (CC BY) license (http://creativecommons.org/licenses/by/4.0/). 